\title{
Cost behavior in e-commerce firms
}

\author{
Josep M. Argilés-Bosch ${ }^{1}$ (D) Josep Garcia-Blandón ${ }^{2} \cdot$ Diego Ravenda $^{3}$
}

Accepted: 11 December 2021

(c) The Author(s) 2022

\begin{abstract}
We conduct empirical research on the flexibility of operating costs of e-commerce firms. With an international sample of firms from different European countries, we find that e-commerce firms have a different cost structure than traditional retail firms, with a lower share of labor costs and cost of goods sold, but a higher share of other operating costs. While we find no significant different behavior in cost of goods sold and labor costs between the two types of firms, e-commerce firms are more flexible in adjusting other operating costs than traditional retail firms when activity decreases. Results are robust to different models, estimations methods and samples. The higher flexibility of e-commerce firms relies on other operating costs, but e-commerce creates qualified jobs with higher wages than traditional retail, with no additional exposure to labor uncertainty for employees.
\end{abstract}

Keywords Cost behavior $\cdot$ E-commerce $\cdot$ Retail firms $\cdot$ Operating costs $\cdot$ Labor costs

\section{Introduction}

E-commerce is the trading or facilitation of trading of products or services using computer networks, such as the internet or online social networks [1]. It has increased dramatically in recent years, usually as a consequence of strategic business decisions and its perceived advantages over traditional commerce in terms of factors such as economic and information efficiency, coordination, and market impact. According to data from eMarketer, worldwide e-commerce sales increased from US\$ 1336 billion in 2014 to US\$ 4280 billion in 2020, a 320\% increase in 6 years, continuing to climb to a forecasted US\$ 6388 billion in 2024, a much greater

Josep M. Argilés-Bosch

josep.argiles@ub.edu

1 Department of Business, Universitat de Barcelona, Barcelona, Spain

2 Department of Economics and Finance, IQS School of Management, Universitat Ramón Llull, Barcelona, Spain

3 Department of Management Control, Accounting and Auditing, TBS Business School, Campus Barcelona, Barcelona, Spain 
increase than for traditional commerce. This represents a rise from $7.4 \%$ share of total global retail sales in 2015 to $18 \%$ in 2020, up to a forecasted $21.8 \%$ in 2024 [2].

We analyze the effects of e-commerce on resource adjustment when activity decreases, in view of the ongoing debate on the economic effects of e-commerce versus traditional business for firms [3-7], employees [8-10] and consumers [11-13] (see Appendix 1 for detailed information about this and other literature reviewed in this study). We focus on the economic advantages of e-commerce over traditional business for firms and, more specifically, on the greater flexibility of the former from the point of view of costs. We analyze the comparative flexibility of firms to adjust resources when sales decrease, using the established business research approach of cost stickiness. Firms exhibit asymmetric cost behavior, with certain costs rising more when activity increases than the corresponding decrease when there is a drop in activity. The economic and business literature describes this behavior as cost stickiness.

Despite the increasing importance of e-commerce in the economy, to the best of the authors' knowledge, there are no empirical studies comparing the economic characteristics and cost behavior of e-commerce firms. More precisely, there is no previous empirical research on the differential asymmetric cost behavior of e-commerce with respect to traditional retail firms. This study contributes to both business and e-commerce research, with an interdisciplinary study in line with following Kauffman and Walden's claims [14] to build an integrated basis for managerial understanding of e-commerce.

We use an international sample of European e-commerce and traditional retail firms and find that e-commerce firms have a different cost structure than traditional retail firms, with a lower share of labor costs (LC) and cost of goods sold (CGS), but a higher share of other operating costs (OTHOP). While we find no significant difference in the behavior in terms of the CGS and LC between the two types of firms, e-commerce firms are more flexible in adjusting OTHOP than traditional retail firms when activity decreases. Results are robust to different models, estimations methods, and samples.

The rest of the paper is organized as follows: the next section reviews the literature and formulates hypotheses; next, we formulate a model, describe the sample, and present results, before finishing with a section on conclusions and implications.

\section{Literature review and hypotheses development}

There is a wealth of business research on e-commerce, usually focusing on commercial, marketing or technical issues related to the logistic efficiency or impact on clients. Kauffman and Walden [14] provide a review on economics and e-commerce from a variety of disciplines with a focus on information systems. Costs of e-commerce adoption have been studied $[15,16]$. To the best of the authors' knowledge, there are almost no empirical studies of the costs and financial performance of e-commerce versus traditional retail trade firms. Koo et al. [17] compare 67 online with 55 click-and-mortar firms, analyzing the contribution of Porter's competitive strategies to firm performance. Brynjolfsson et al. [12] evaluate the consumer 
surplus generated for consumers by e-commerce with respect to traditional firms. Stylianou et al. [18] examine prices and costs from pharmaceutical retailers that sell exclusively on the internet compared to retailers with both conventional and internet channels. They collected data from the firms' websites and found small but significant differences in prices and larger differences in costs. Prices were lower on the internet, but the costs to the consumer were higher. These studies use fragmentary data rather than the complete accounting data of the whole firms used in the study.

Since the seminal study by Anderson et al. [19], cost stickiness research has usually analyzed selling, general and administrative expenses (SG\&A) [20-23] and total operating costs (TOP) [24, 25]. Few studies have analyzed LC [26-29]. Various industries [30], including international comparisons and settings [31] or certain specific contexts or industries, have also been analyzed, such as the air transportation industry [32], manufacturing enterprises [33], hospitals [34], therapy clinics [35], small and medium sized firms [27], and local public enterprises [36], among others. However, to the best of the authors' knowledge, no empirical research has been conducted on the comparative resource adjustment of e-commerce in comparison to traditional retail firms when activity decreases, as can be seen in the Appendix 1, which summarizes our literature review.

Previous research has identified various factors causing cost stickiness, with the most important being the managers' inability to adjust resources because they are not flexible enough to react in a timely manner, the deliberate decision to keep resources because they have some expectations or specific interests, and/or the fixity of certain costs influencing the ability to react in the short term [24, 37, 38].

The traditional cost behavior model distinguishes between variable and fixed costs [39]. Since their inception, economic theory [40, 41] and cost accounting [42, p. 222-238] have rebutted the concepts of fixed and variable costs, recognizing that they are controversial concepts. They have also assumed that most costs are conventionally considered variable in the long term and fixed in the short time. More recently, the activity-based costing approach considers that all costs, including overhead costs, are variable [43, p. 239]. Some authors argue that fixed costs are the most variable and rapidly increasing costs [44, p. 225]. According to Cooper and Kaplan [45], managers erroneously conclude that some costs are fixed because they fail to reduce them. The activity-based costing model stresses the importance of transactions as cost drivers and criticizes the use of volume drivers to allocate costs to products through the traditional cost accounting models [46]. However, the two models agree to a certain extent, considering that fixed costs increase in the long term. The differences are more based on the emphasis. The activity-based costing model emphasizes the variable nature of overhead costs and the convenience of shifting from volume to transactions as a criteria for allocating costs to products and services $[47,48]$. According to these authors, the real driver of costs is the complexity that firms have acquired in the long run to fulfill their objectives They also recognize that there is no automatic adjustment of overhead costs when activity decreases. They increase easily, but there are a great deal of rigidity that makes decreasing them difficult. They argue that the variability of overhead costs should be measured in terms of transactions rather than in terms of volume. The proportionality of costs is also called into question 
[34, 49]. However, despite the controversial distinction between the two types of costs, the traditional cost behavior model of and the empirical research on cost stickiness assume that variable costs are proportional to activity and that fixed costs do not change with activity in the short term and within the firms' relevant range of activity [50, p. 179]. With this approach, variable costs are assumed to display the same pattern and change in both phases of increasing and decreasing activity, and thus do not show sticky behavior, while fixed costs do exhibit sticky behavior.

Therefore, in the case of variable costs, the magnitude of the change depends only on the extent of the change, but not on its direction [51]. Similarly, the costs of goods sold are recorded automatically in the profit and loss statement, depending on revenues. In the retail trade industry, the costs of goods sold are the goods sold valued at acquisition costs. They are considered variable costs. According to this argument, such costs should not display sticky behavior, or their stickiness should be insignificant. They are related to the units of products or services sold by firms. They appear in the profit and loss statement depending on the units sold, increasing with increasing sales and decreasing similarly when sales decrease. There are no expected differences in the sticky behavior of such variable costs between e-commerce and traditional retail.

Fixed costs are more related to the maintenance of the structure required to keep the firm working. As the characteristics of e-commerce and traditional retail firms are different, the structure of fixed costs and their behavior is expected to differ between the two types of firms. Traditional retail firms rely on physical presence and the use of brick-and-mortar outlets. They offer products to their customers face-toface in a store that the business owns or rents. Therefore, they need higher investments in fixed assets, as well as expenses related to their depreciation, rent, maintenance, and sustaining their working conditions, such as electricity and heat. They also need a higher number of employees to conduct their sales. In contrast, e-commerce conducts business with fewer employees. The OECD [52, p. 66-67] reports greater revenue per employee in internet businesses than in their traditional counterparts. Falk and Hagsten [4] find greater labor productivity growth in e-commerce firms across 14 European countries. Like traditional retail, e-commerce requires a lot of unqualified employment, but its core business is based on qualified work. However, in both cases, as its activities are less dependent on physical locations, e-commerce firms may more easily outsource certain tasks and/or use non-standard employment, or even hire employees in countries or locations with cheap wages and low social security contributions or labor protection. Firms' sales in these locations may be tiny, but the employees hired in these locations may work in other countries where sales are high but may have less favorable labor jurisdictions from the point of view of the firms' costs. The International Labor Organization [53] reports an increasing use of non-standard employment, which is particularly significant in e-commerce firms. Some authors $[54,55]$ stress that e-commerce exacerbates the usual monitoring problems for tax and labor authorities. Therefore, they are more flexible not only in terms of contracting employees in the most favorable labor locations and using them to work in other locations, but also for adjusting human resources needs to fluctuations in demand. 
In most business dimensions, flexibility is a distinctive feature of e-commerce. Saini and Johnson [56] identify a significant relationship between firm flexibility and e-commerce performance. Speed of change, real-time pricing, customer interactions, and the low cost of distributing product information are important advantages and characteristics of e-commerce firms, among others [57]. E-commerce is knowledgeintensive and technology-based, creating new value through the increased number and variety of information, services, and products available to the customer. E-commerce relies more on intangibles and technological investments, which are more exposed to obsolescence, shorter lifetime periods and, consequently, higher depreciation rates. Their businesses probably require greater coordination of a wide range of activities conducted in different places, such as promotion, customer enquiries and delivery. It also requires constant innovation, the development of information systems and their integration into daily operations [5]. According to these authors, the important benefits of e-business include efficient information/knowledge sharing and data analysis, as well as working without any distance limitations. Organizational innovation and the automation of the company's activities are also crucial features of this type of business. Their specific business model makes e-commerce firms more flexible than traditional firms. There are abundant flexibilities that come with electronic commerce [58]. Bieńkowska and Sikorski [59] argue that flexibility for applying organizational solutions, adapting to unforeseen changes, and using and reassigning resources pragmatically to adapt to changing circumstances is a key feature of e-commerce, which is required and determined by its dynamic environment. As a consequence, e-commerce firms are more prepared to adapt flexibly to changing circumstances, including a drop in activity, as well as getting rid of unused resources, if necessary.

We therefore formulate the following hypotheses:

H1 There are no differences in variable cost behavior between e-commerce and traditional retail firms.

H2 Fixed costs are less sticky in e-commerce firms than in traditional retail firms.

\section{Model development}

Based on previous studies [21, 26, 28-30, 60], we formulate the following model to explain cost behavior:

$$
\begin{aligned}
\Delta \log O P_{i, t}= & \beta_{0}+\beta_{1} \cdot \Delta \log R E V_{i, t}+\beta_{2} \cdot D_{i, t} \cdot \Delta \log R E V_{i, t}+\beta_{3} \cdot D_{i, t} \cdot \Delta \log R E V_{i, t} \cdot E_{C O M} \\
& +\sum_{i=1}^{N} \gamma_{4} \cdot D_{i, t} \cdot \Delta \log R E V_{i, t} \cdot \operatorname{CONTROLS}_{i, t}+\delta_{1} \cdot \text { ECOM }_{i, t} \\
& +\sum_{i=2}^{N} \delta \cdot \operatorname{CONTROLS}_{i, t}+\varepsilon_{i, t}
\end{aligned}
$$


where each observation refers to firm $i$ in year $t, \beta, \gamma$ and $\delta$ are the parameters to be estimated, and $\varepsilon$ is the error term, $\triangle \log O P$ is the log-change in operating costs (OP), $\triangle \log R E V$ is the log-change in revenues, and $D$ is a dummy indicating that revenues decrease with respect to the previous year. ECOM is our experimental variable, a dummy indicating with value one (and zero otherwise) that a given firm is coded as retail trade via the internet. CONTROLS are various control variables likely to influence LC stickiness, which have also been used in previous studies. The Appendix 2 gives a list and full description of these and all other variables.

Different OP measures are used. More precisely, we use CGS, indicating the value (at acquisition cost) of merchandise sold, with similar behavior to variable costs. We also use LC and OTHOP, with similar behavior to fixed costs, as well as considering TOP.

As mentioned, we include control variables commonly used in previous research, such as employee intensity (EMPINT), asset intensity (ASSINT), return on assets (ROA), indebtedness (DEBTTA), successive revenue decreases (DSUC), loss in prior year (LOSPRY), and dummies for firms (FIRM) years (YEAR) and countries (COUN$T R Y)$. The definition and calculation of these variables is shown in the Appendix 2.

\section{Sample}

We selected the retail trade sector because it is the only industry that distinguishes between firms selling through both traditional and e-commerce channels, in the most important and common industry statistical classifications, such as the Statistical Classification of Economic Activities in the European Union, also known as the NACE (the French title Nomenclature générale des Activités économiques dans les Communautés Européennes). The NACE code 47 (retail except of motor vehicles and motorcycles) distinguishes between firms classified as retail trade via internet (NACE code 4791) and traditional retail firms (the remaining codes in NACE code 47).

We downloaded all the available data for firms in the European AMADEUS database for the last ten years when we started the study (2010 to 2019), in the two-digit industry code 47 . AMADEUS contains comprehensive information on around 21 million companies over ten years across both Western and Eastern Europe. Despite this huge number of firms, there are only 411,295 active firms with a known industrial activity code in our subscription to the database, which are the biggest firms in the different European countries.

The first download contained 210,888 firm-year observations. Table 1 shows sample details, including sample construction. A total of 158 observations with no firm identification were discarded. As is usual in empirical research on cost stickiness, to clean the sample from the exceptional effects of mergers, acquisitions and other extraordinary operations, we dropped 92,571 observations with revenue changes of $50 \%$, either upward or downward. To prevent any likely bias from mistakes in the database, we additionally dropped 1695 observations with negative revenues or total operating costs. Considering the necessary lags and information in all our independent variables and total operating costs, our final sample consists of 83,266 firm-year 


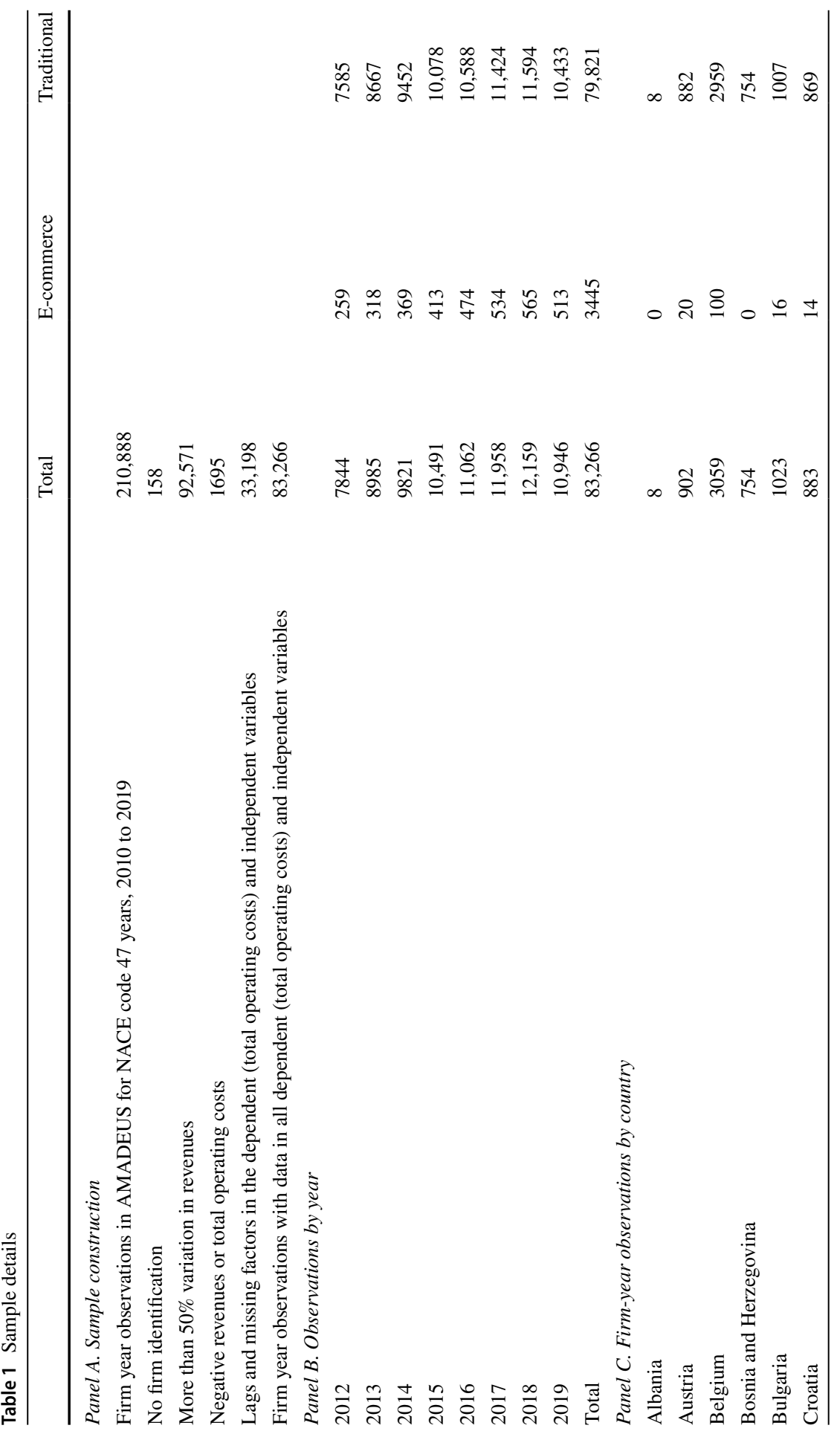




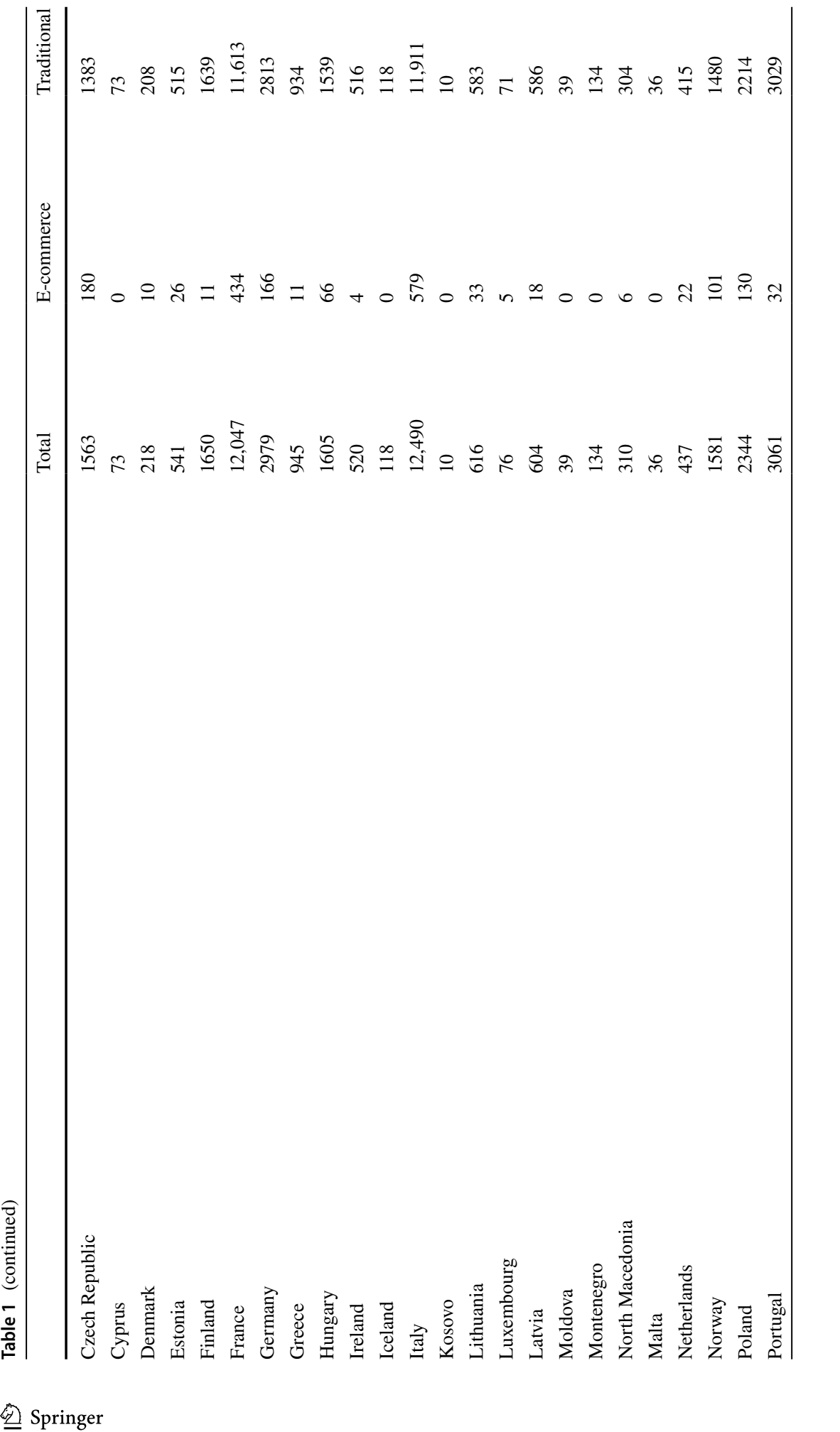




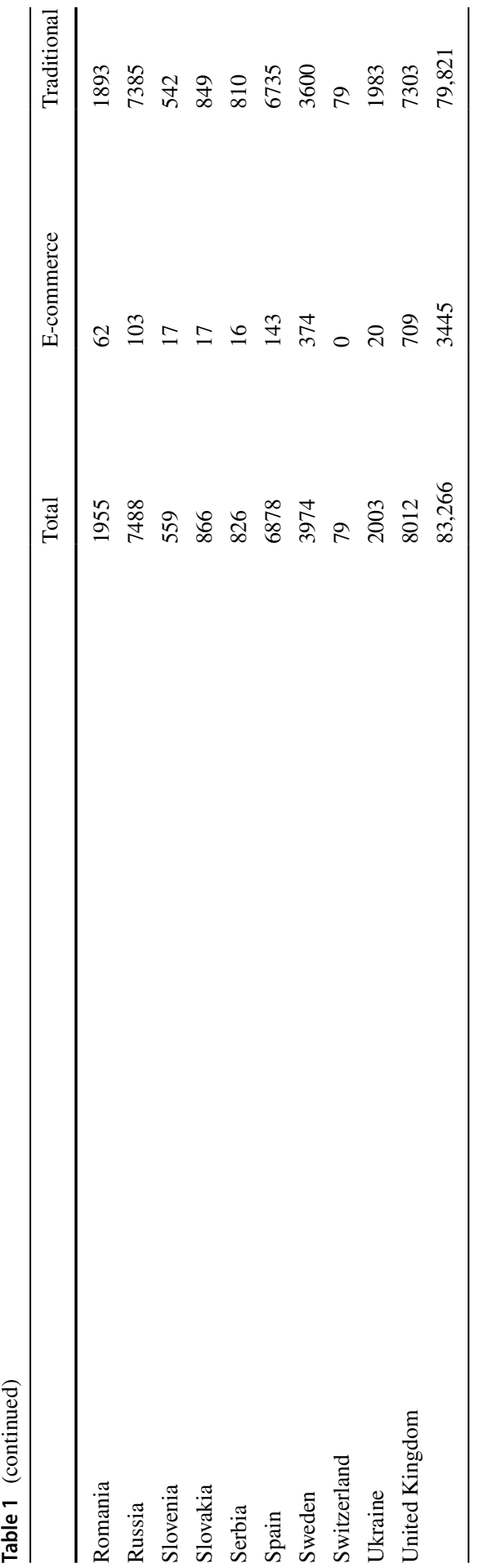


observations (see Panel A in Table 1). However, fewer observations are available for the estimations with the different types of operating costs, as shown in the estimations displayed in Tables 4, 5, 6, 7, and 8.

We code as e-commerce any firms with NACE code 4791, and we consider all remaining firms as traditional brick-and-mortar firms. Panel B in Table 1 displays observations by year, distinguishing between e-commerce and traditional retail firms, with a total of 3445 firm-year observations for the former, a total of $4.1 \%$ of all firm-year observations in our sample, compared to the corresponding number of 79,821 in the case of traditional firms.

Panel $\mathrm{C}$ in Table 1 shows the number of observations by country. The highest numbers belong to firms in the biggest European countries, such as Italy, France, the United Kingdom, Russia and Spain, but Germany is underrepresented in the sample, contributing with a lower number of observations than Sweden, Belgium and Portugal.

As is common in empirical research on business, in order to avoid biased results due to influential cases, we winsorize all continuous variables at $0.5 \%$ in each tail. Table 2 displays descriptive statistics for dependent and independent variables, as well as other sample characteristics. In accordance with worldwide trends, as mentioned in the introduction, the revenues of e-commerce firms grow more than traditional firms over the period studied (see Panel B). Consequently, their costs also grow more (see Panel A). They need fewer employees and less investment in assets and, therefore, their ratios of employee and asset intensity are lower, but the difference is non-significant at $p<0.1$ in the case of asset intensity. Surprisingly, e-commerce firms are more indebted, probably because they grow more and have higher financing needs. Their profitability is lower, probably because of their higher financial expenses and growth orientation. In accordance with previous data, there is a significant association between traditional commerce (versus e-commerce) and decreasing sales in the current year and in two successive years. Moreover, the share of e-commerce firms' observations with losses in the previous year is higher than the corresponding figure for traditional firms. Panel B in Table 1 shows these data.

Panel $\mathrm{C}$ in Table 1 shows additional interesting characteristics. E-commerce firms have bigger revenues and lower number of employees, and pay considerably higher wages per employee, probably because they rely more on qualified work and need less unqualified work to perform their operations. This is in line with Steinfield et al. [61], who found greater labor cost efficiencies in e-commerce in case studies in the Netherlands. The share of fixed assets is lower and also the share of depreciation costs over total operating costs. Their cost structure is different from the cost structure of traditional firms. The cost of goods sold is lower because they probably have lower acquisition costs and a more favorable product mix. Labor costs are almost $10 \%(1-11.26 / 12.42)$ lower on average, which is much less than the considerably lower average number of employees, at 41\% (1-261.4/444.8) less than traditional retail firms. Finally, the share of other operating costs is higher because they require more coordination, support activities and research and development.

Table 3 shows Pearson correlations between the independent variables. Correlations between non-interaction variables are low (the highest value is -0.458 between $D S U C$ and $\triangle \log R E V$ ), but there are some high and significant correlations between 


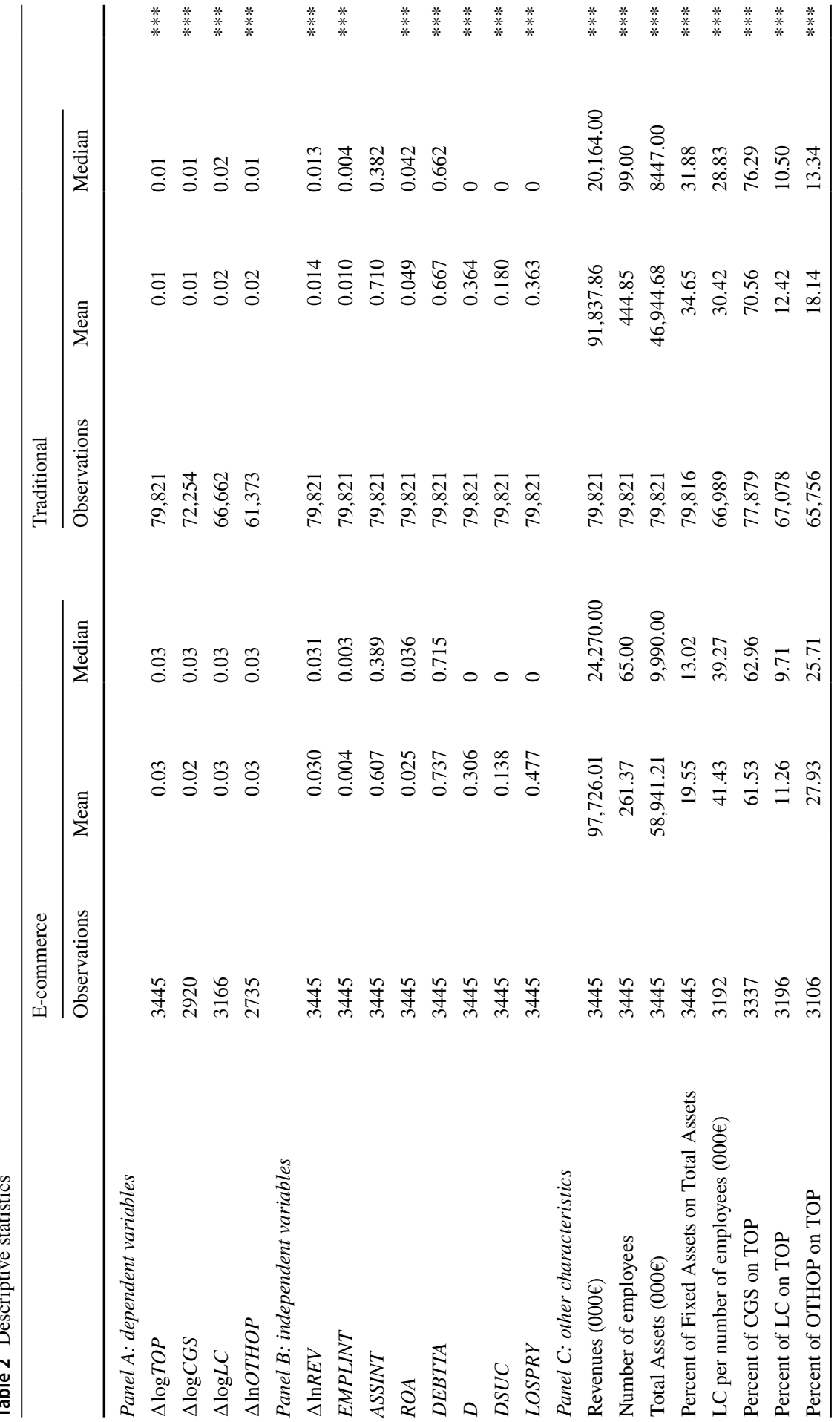




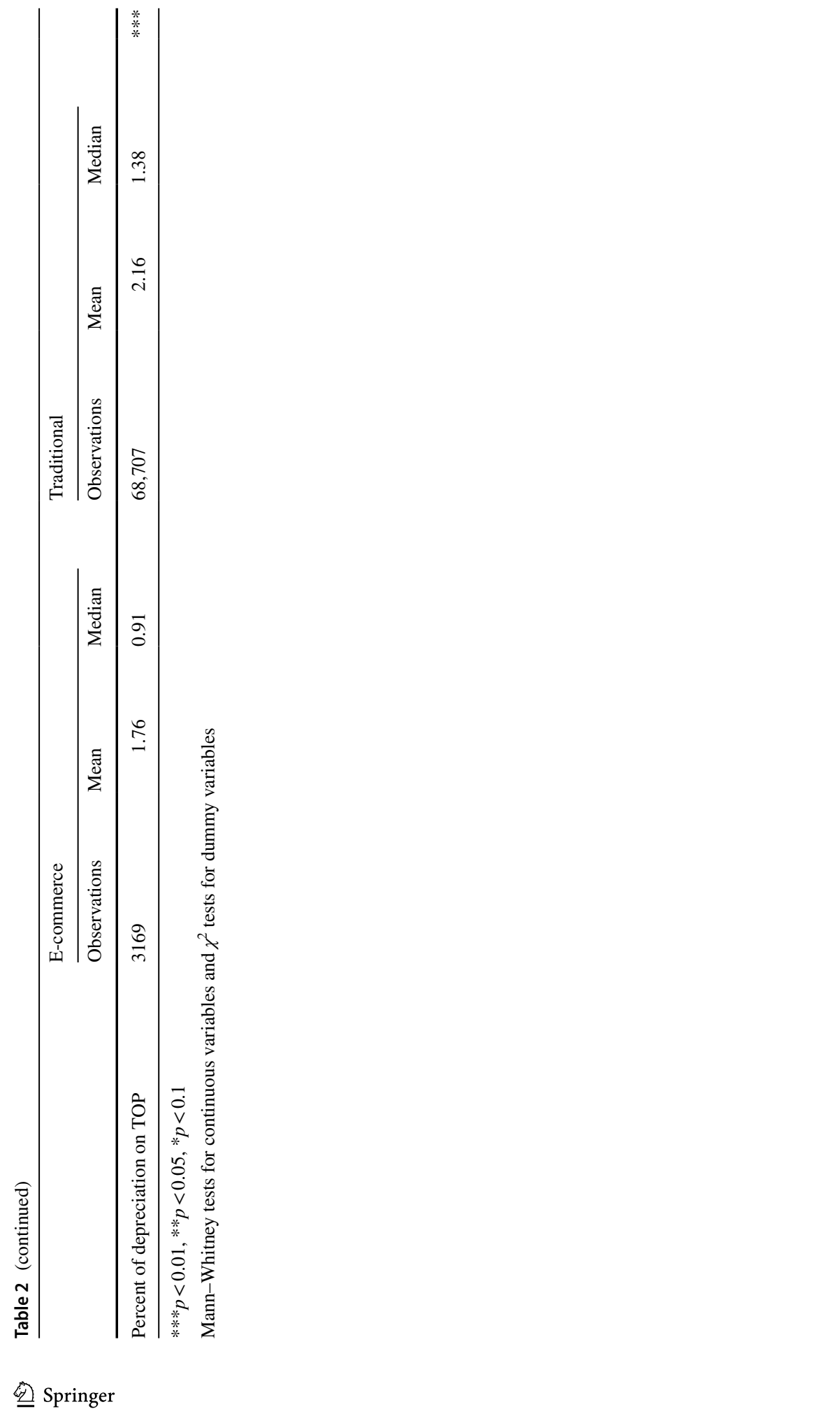


Table 3 Pearson correlations between standalone independent variables

\begin{tabular}{|c|c|c|c|c|c|c|c|c|}
\hline & $\Delta \log R E V$ & ECOM & EMPLINT & ASSINT & $R O A$ & DEBTTA & DSUC & LOSPRY \\
\hline$\Delta \log R E V$ & 1 & & & & & & & \\
\hline ECOM & $0.051 * * *$ & 1 & & & & & & \\
\hline EMPLINT & $-0.164 * * *$ & $-0.051 * * *$ & 1 & & & & & \\
\hline ASSINT & $-0.084 * * *$ & $-0.01^{* * *}$ & $0.145 * * *$ & 1 & & & & \\
\hline$R O A$ & $0.161^{* * * *}$ & $-0.038 * * *$ & $-0.062 * * *$ & $-0.075^{* * *}$ & 1 & & & \\
\hline DEBTTA & -0.005 & $0.04 * * *$ & $-0.068 * * *$ & $-0.102 * * *$ & $-0.43^{* * *}$ & 1 & & \\
\hline DSUC & $-0.458 * * *$ & $-0.022 * * *$ & $0.121 * * *$ & $0.048^{* * *}$ & $-0.143^{* * *}$ & $0.032 * * *$ & 1 & \\
\hline LOSPRY & 0.001 & $0.047 * * *$ & $0.02 * * *$ & $0.068 * * *$ & $-0.26^{* * *}$ & $0.227 * * *$ & $0.025^{* * *}$ & 1 \\
\hline
\end{tabular}

$* * * p<0.01, * * p<0.05, * p<0.1$

interaction variables (not displayed for the sake of simplicity), as is frequent in samples with such variables. The highest value is 0.804 between $D \cdot \Delta \log R E V$ and $D \bullet \triangle \log R E V$ DEBTTA. The highest variance inflation factors are 8.5 and 5.2 for these variables, respectively, which fall within the accepted thresholds of 5 and 10 , respectively [62, p. 76, and 63, p. 409], that some authors consider indications of moderate or serious collinearity problems. As the condition index is 10.9, well below the thresholds of 15 or 30 , conventionally considered to be associated with collinearity concerns or serious collinearity concerns respectively [64, 65], collinearity is not considered likely to affect estimations.

\section{Results}

Given the panel data structure of our data and the Hausmann tests, we run fixedeffects estimations. Dummies for firms are not displayed for the sake of simplicity. As some interesting industry effects are omitted for collinearity in fixed-effects estimations, we also run industry-year interactions with firm fixed effects and random effects controlling for dummies for industry. The Breusch-Pagan/Cook-Weisberg for heteroskedasticity and modified Wald test for groupwise heteroskedasticity indicate that our models display heteroskedasticity in most cases and, consequently, we perform estimations with robust standard errors.

Table 4 shows estimations for a reduced model of operating costs depending on $\Delta \log R E V$ and the interaction variable $D \cdot \Delta \log R E V$. As expected, there is sticky behavior in TOTOP, LC and OTHOP, particularly in the two latter costs. For example, focusing on Column (1) in this table, total operating costs increased $0.955 \%$ per $1 \%$ increase in revenues, but they decreased slightly less, $0.9267 \%(0.955-0.0283)$ when revenues decreased by $1 \%$. The sticky behavior is more pronounced for LC and OTHOP, with significant $\beta_{2}$ coefficients of -0.099 and -0.114 at $p<0.01$, respectively. However, CGS displays anti-sticky behavior, decreasing more when revenues decrease than they increase in the increasing trajectory: a significant (but only at $p<0.1$ ) positive $\beta_{2}$ coefficient of 0.0186 . This may be explained by a changing product mix and/or the application of lower acquisition costs by suppliers in 
Table 4 Fixed-effects estimations of operating costs depending on revenues

\begin{tabular}{lllll}
\hline & $(1)$ & $(2)$ & $(3)$ & $(4)$ \\
Variables & $\Delta \log T O P$ & $\Delta \log C G S$ & $\Delta \log L C$ & $\Delta \log O T H O P$ \\
\hline$\Delta \log R E V$ & $0.955^{* * *}$ & $1.005^{* * *}$ & $0.626^{* * *}$ & $0.729 * * *$ \\
& $(0.00306)$ & $(0.00521)$ & $(0.0106)$ & $(0.0148)$ \\
$D \cdot \Delta \log R E V$ & $-0.0283^{* * *}$ & $0.0186^{*}$ & $-0.0990^{* * *}$ & $-0.114^{* * *}$ \\
& $(0.00711)$ & $(0.00954)$ & $(0.0229)$ & $(0.0313)$ \\
Constant & $0.000551^{* * *}$ & $-0.00163^{* * *}$ & $0.0119 * * *$ & $0.00567^{* * *}$ \\
& $(0.000142)$ & $(0.000194)$ & $(0.000427)$ & $(0.000559)$ \\
Observations & 83,266 & 75,174 & 69,828 & 64,108 \\
Number of firms & 15,828 & 14,761 & 13,399 & 12,657 \\
Firm fixed effects & Yes & Yes & Yes & Yes \\
R-sq overall & $0.8896^{* * *}$ & $0.7767^{* * *}$ & $0.2962^{* * *}$ & $0.2052^{* * * *}$ \\
\hline
\end{tabular}

Robust standard errors in parentheses

$* * * p<0.01, * * p<0.05, * p<0.1$

periods of decreasing activity, although that drop in sales may produce higher damaged and obsolete goods than the increase in sales, which would require inventory write-downs and, consequently, a lower decrease in costs.

Table 5 shows the results of the estimations of the full model formulated in Eq. (1). Dummies for firms and years are not shown for the sake of simplicity. All estimations show significant goodness-of-fit with R-squared overall ranging from 0.1977 to 0.8917 for other and total operating costs, respectively. There is no significant relationship (at $p<0.1$ ) between our experimental variable $(D \cdot \Delta \log R E V \cdot E C O M)$ and TOTOP, CGS and LC, thus indicating that there are no significant differences between e-commerce and traditional retail firms in the sticky behavior of costs of goods sold and labor costs. In contrast, $\beta_{3}$ is positive and significant (at $p<0.01)$ for OTHOP, indicating that e-commerce firms are more flexible than traditional firms in adjusting other operating costs when activity decreases. Under such circumstances, they react with higher reductions to these costs and, therefore, with less sticky behavior. Consequently, these results provide support for H1, but only limited support for H2. This hypothesis is supported for OTHOP, but not for LC.

The dummy variable ECOM is removed from the regressions because of collinearity, given that panel data estimations with fixed effects remove all variables that do not change their value for individual firms over the different periods. Most control variables display the expected result. All operating costs increase less in more profitable and indebted firms, as well as in periods of losses in previous years (see the standalone variables ROA, DEBTTA and LOSPRY). Moreover, results with the interaction variables confirm expectations about higher sticky behavior in all costs for higher asset intensity, while indebtedness and sales decrease in successive years are associated with less stickiness, also as expected, in two out of four columns. The coefficient of the interaction variable with employee intensity surprisingly displays opposite signs: negative and significant in Column (2), and positive and significant 
Table 5 Fixed-effects estimations of Eq. (1). Full sample

\begin{tabular}{|c|c|c|c|c|}
\hline & (1) & (2) & (3) & (4) \\
\hline Variables & $\triangle \log T O P$ & $\Delta \log C G S$ & $\Delta \log L C$ & $\triangle \log O T H O P$ \\
\hline \multirow[t]{2}{*}{$\triangle \log R E V$} & $0.968 * * *$ & $1.011 * * *$ & $0.638 * * *$ & $0.763 * * *$ \\
\hline & $(0.00291)$ & $(0.00532)$ & $(0.0110)$ & $(0.0150)$ \\
\hline \multirow[t]{2}{*}{$D \cdot \Delta \log R E V$} & -0.00742 & $0.0580 * * *$ & $-0.194 * * *$ & $-0.236 * * *$ \\
\hline & $(0.0139)$ & $(0.0225)$ & $(0.0456)$ & $(0.0578)$ \\
\hline \multirow[t]{2}{*}{$D \cdot \Delta \log R E V \cdot E C O M$} & 0.0111 & 0.0132 & -0.0681 & $0.237 * * *$ \\
\hline & $(0.0206)$ & $(0.0561)$ & $(0.0773)$ & $(0.0792)$ \\
\hline \multirow[t]{2}{*}{$D \cdot \Delta \log R E V \cdot E M P L I N T$} & -0.0637 & $-0.237 *$ & $4.590 * * *$ & $2.574^{*}$ \\
\hline & $(0.104)$ & $(0.143)$ & $(0.995)$ & $(1.468)$ \\
\hline \multirow[t]{2}{*}{$D \cdot \Delta \log R E V \cdot A S S I N T$} & $-0.0284 * * *$ & $-0.0269 * * *$ & $-0.0310 * * *$ & $-0.0261 * *$ \\
\hline & $(0.00355)$ & $(0.00808)$ & $(0.00670)$ & $(0.0117)$ \\
\hline \multirow[t]{2}{*}{$D \cdot \Delta \log R E V \cdot R O A$} & $0.187 * * *$ & -0.0283 & $0.252 * *$ & 0.238 \\
\hline & $(0.0432)$ & $(0.0643)$ & $(0.126)$ & $(0.153)$ \\
\hline \multirow[t]{2}{*}{$D \cdot \Delta \log R E V \cdot D E B T T A$} & 0.00775 & -0.0124 & $0.0799 *$ & $0.142 * *$ \\
\hline & $(0.0170)$ & $(0.0210)$ & $(0.0437)$ & $(0.0631)$ \\
\hline \multirow[t]{2}{*}{$D \cdot \Delta \log R E V \cdot D S U C$} & $0.0436 * * *$ & 0.00324 & $0.115 * * *$ & -0.00267 \\
\hline & $(0.00971)$ & $(0.0133)$ & $(0.0340)$ & $(0.0432)$ \\
\hline \multirow[t]{2}{*}{$D \cdot \Delta \log R E V \cdot L O S P R Y$} & -0.0161 & 0.0111 & -0.0269 & $0.0747^{*}$ \\
\hline & $(0.0100)$ & $(0.0142)$ & $(0.0339)$ & $(0.0444)$ \\
\hline \multirow[t]{2}{*}{ EMPLINT } & -0.0254 & -0.00858 & $0.488 * * *$ & $-0.303 *$ \\
\hline & $(0.0179)$ & $(0.0262)$ & $(0.146)$ & $(0.170)$ \\
\hline \multirow[t]{2}{*}{ ASSINT } & -0.000649 & -0.00158 & -0.000789 & 0.00166 \\
\hline & $(0.000566)$ & $(0.00118)$ & $(0.000889)$ & $(0.00203)$ \\
\hline \multirow[t]{2}{*}{$R O A$} & $-0.0858 * * *$ & $-0.0583 * * *$ & $-0.0388 * * *$ & $-0.215^{* * *}$ \\
\hline & $(0.00244)$ & $(0.00303)$ & $(0.00514)$ & $(0.00911)$ \\
\hline \multirow[t]{2}{*}{ DEBTTA } & $-0.0123 * * *$ & $-0.00476^{* * *}$ & $-0.0125^{* * *} *$ & $-0.0279 * * *$ \\
\hline & $(0.00126)$ & $(0.00151)$ & $(0.00268)$ & $(0.00435)$ \\
\hline \multirow[t]{2}{*}{ DSUC } & -0.000214 & -0.000318 & -0.000374 & -0.00185 \\
\hline & $(0.000305)$ & $(0.000452)$ & $(0.000965)$ & $(0.00129)$ \\
\hline \multirow[t]{2}{*}{$L O S P R Y$} & $-0.00653 * * *$ & $-0.00498 * * *$ & $-0.00450^{* * *}$ & $-0.0187 * * *$ \\
\hline & $(0.000242)$ & $(0.000437)$ & $(0.000762)$ & $(0.00109)$ \\
\hline \multirow[t]{2}{*}{ Constant } & $0.0208 * * *$ & $0.0111 * * *$ & $0.0230 * * *$ & $0.0565 * * *$ \\
\hline & $(0.00102)$ & $(0.00136)$ & $(0.00241)$ & $(0.00376)$ \\
\hline Observations & 83,266 & 75,174 & 69,828 & 64,108 \\
\hline Number of firms & 15,828 & 14,761 & 13,399 & 12,657 \\
\hline Year & Yes & Yes & Yes & Yes \\
\hline Firm fixed effects & Yes & Yes & Yes & Yes \\
\hline R-sq overall & $0.8917 * * *$ & $0.7775 * * *$ & $0.2956 * * *$ & $0.1977 * * *$ \\
\hline
\end{tabular}

Robust standard errors in parentheses

$* * * p<0.01, * * p<0.05, * p<0.1$ 
in Columns (3) and (4). The moderating effect of employee intensity on the sticky behavior of labor costs (Column (3)) can be explained in terms of the more urgent need to cut labor costs in firms with higher employee intensity.

Given that our sample includes a much larger number of traditional retail firms compared to e-commerce firms, results with the full sample might be biased by this unbalanced number of observations. Accounting and business research use propensity scores as a matching procedure to remove concerns about endogeneity affecting results $[66,67]$. We therefore use the propensity score method to produce a matched sample with a similar number of observations and characteristics in the two subsamples. For all countries with e-commerce observations and data on total operating costs, we run logistic regressions in which the dependent variable ECOM depends on size, measured as total assets, and the independent standalone variables in Eq. 1, EMPLINT, ASSINT, ROA, DEBTTA, LOSPRY and DSUC, to obtain a one-to-one sample and avoiding firms being matched more than once. Despite differences in the results with the propensity score-matched sample for control variables, they are essentially the same with respect to our variable of interest, $D \cdot \Delta \log R E V \cdot E C O M$, as can be seen in Table 6. According to these results, e-commerce business does not significantly influence the asymmetric behavior of CGS and LC (see Columns (2) and (3)), but the positive significant sign of the interaction variable $D \cdot \triangle \log R E V \cdot E C O M$ in Column (4) indicates that e-commerce firms are more flexible in cutting OTHOP when activity decreases. Therefore, once again, our results support H1, and H2 is again supported by our results for OTHOP, but not for LC. ECOM is again removed for collinearity.

To avoid concerns about cross-sectional correlation, we perform Fama-MacBeth estimations. The results, shown in Table 7, provide reinforced results for our experimental variable. While there are no significant coefficients for CGS and LC for the whole and propensity-matched samples (see Columns 1, 2, 4 and 5), the coefficient is positive and significant for OTHOP in both samples (see Columns (3) and (6)). As the Fama-MacBeth procedure performs cross-section estimations by year, the dummy variable is now not removed because of collinearity.

Fixed-effects estimation does not allow us to control for country, given that the necessary dummies used are excluded for collinearity. To rule out any possibility that specific country characteristics would distort our results, we perform fixedeffects estimations, including interaction variables with dummies for year and country, and results (not tabulated) are similar for our experimental variable in the full and propensity score-matched samples: significant positive coefficient for OTHOP (at $p<0.01$ and $p<0.1$ for the full and matched sample, respectively) and non-significant coefficients for CGS and LC, with the exception of a negative and significant (at $p<0.1$ ) coefficient for CGS in the matched sample. We additionally run random-effects estimations, adding dummies for countries at Eq. 1 and, again, results (not tabulated for simplicity) are similar with respect to our variable of interest: non-significant (at $p<0.1)$ coefficients for CGS and LC in all samples, and significant positive coefficients for OTHOP in the full and matched sample (at $p<0.01$ and $p<0.1$ respectively).

Some of the few empirical studies on LC stickiness attribute the asymmetric LC behavior to hiring and firing costs mandated by the employment protection 
Table 6 Fixed-effects estimations of Eq. (1). Propensity score-matched sample by country

\begin{tabular}{|c|c|c|c|c|}
\hline Variables & $\begin{array}{l}(1) \\
\Delta \log T O P\end{array}$ & $\begin{array}{l}(2) \\
\Delta \log C G S\end{array}$ & $\begin{array}{l}(3) \\
\Delta \log L C\end{array}$ & $\begin{array}{l}\text { (4) } \\
\triangle \log O T H O P\end{array}$ \\
\hline$\Delta \log R E V$ & $\begin{array}{l}0.956 * * * \\
(0.0127)\end{array}$ & $\begin{array}{l}1.007 * * * \\
(0.0279)\end{array}$ & $\begin{array}{l}0.551 * * * \\
(0.0475)\end{array}$ & $\begin{array}{l}0.806^{* * * *} \\
(0.0532)\end{array}$ \\
\hline$D \cdot \Delta \log R E V$ & $\begin{array}{l}0.172 * * * \\
(0.0596)\end{array}$ & $\begin{array}{l}0.253 * * \\
(0.112)\end{array}$ & $\begin{array}{l}-0.138 \\
(0.198)\end{array}$ & $\begin{array}{l}-0.578 * * \\
(0.235)\end{array}$ \\
\hline$D \cdot \Delta \log R E V \cdot E C O M$ & $\begin{array}{l}-0.0371 \\
(0.0432)\end{array}$ & $\begin{array}{l}-0.0945 \\
(0.0844)\end{array}$ & $\begin{array}{l}0.0292 \\
(0.146)\end{array}$ & $\begin{array}{l}0.434 * * \\
(0.181)\end{array}$ \\
\hline$D \cdot \Delta \log R E V \cdot E M P L I N T$ & $\begin{array}{l}-1.111 \\
(1.057)\end{array}$ & $\begin{array}{l}9.361 * * \\
(4.221)\end{array}$ & $\begin{array}{l}1.584 \\
(1.259)\end{array}$ & $\begin{array}{l}11.32 \\
(7.733)\end{array}$ \\
\hline$D \cdot \Delta \log R E V \cdot A S S I N T$ & $\begin{array}{l}-0.101 * * * \\
(0.0316)\end{array}$ & $\begin{array}{l}-0.0147 \\
(0.0330)\end{array}$ & $\begin{array}{l}-0.0696 \\
(0.0536)\end{array}$ & $\begin{array}{l}-0.0878^{*} \\
(0.0456)\end{array}$ \\
\hline$D \cdot \Delta \log R E V \cdot R O A$ & $\begin{array}{l}-0.00569 \\
(0.0839)\end{array}$ & $\begin{array}{l}0.102 \\
(0.170)\end{array}$ & $\begin{array}{l}0.262 \\
(0.273)\end{array}$ & $\begin{array}{l}-0.589 * * \\
(0.285)\end{array}$ \\
\hline$D \cdot \Delta \log R E V \cdot D E B T T A$ & $\begin{array}{l}0-.0729 \\
(0.0475)\end{array}$ & $\begin{array}{l}-0.0949 \\
(0.0838)\end{array}$ & $\begin{array}{l}0.0277 \\
(0.130)\end{array}$ & $\begin{array}{l}0.0340 \\
(0.135)\end{array}$ \\
\hline$D \cdot \Delta \log R E V \cdot D S U C$ & $\begin{array}{l}0.00163 \\
(0.0404)\end{array}$ & $\begin{array}{l}-0.0492 \\
(0.103)\end{array}$ & $\begin{array}{l}0.0984 \\
(0.142)\end{array}$ & $\begin{array}{l}0.0477 \\
(0.136)\end{array}$ \\
\hline$D \cdot \Delta \log R E V \cdot L O S P R Y$ & $\begin{array}{l}-0.00772 \\
(0.0331)\end{array}$ & $\begin{array}{l}-0.0592 \\
(0.105)\end{array}$ & $\begin{array}{l}0.0917 \\
(0.141)\end{array}$ & $\begin{array}{l}0.167 \\
(0.121)\end{array}$ \\
\hline EMPLINT & $\begin{array}{l}0.00592 \\
(0.100)\end{array}$ & $\begin{array}{l}1.730 * * \\
(0.732)\end{array}$ & $\begin{array}{l}1.744 * \\
(0.968)\end{array}$ & $\begin{array}{l}-0.729 \\
(0.629)\end{array}$ \\
\hline ASSINT & $\begin{array}{l}-0.00136 \\
(0.00315)\end{array}$ & $\begin{array}{l}-0.00763 \\
(0.00657)\end{array}$ & $\begin{array}{l}-0.000352 \\
(0.00278)\end{array}$ & $\begin{array}{l}-0.0165^{*} \\
(0.00889)\end{array}$ \\
\hline$R O A$ & $\begin{array}{l}-0.0821 * * * \\
(0.00726)\end{array}$ & $\begin{array}{l}-0.0412 * * * \\
(0.0126)\end{array}$ & $\begin{array}{l}-0.0542 * * * \\
(0.0189)\end{array}$ & $\begin{array}{l}-0.232 * * * \\
(0.0202)\end{array}$ \\
\hline DEBTTA & $\begin{array}{l}-0.0125 * * * \\
(0.00320)\end{array}$ & $\begin{array}{l}0.000270 \\
(0.00736)\end{array}$ & $\begin{array}{l}-0.0297 * * * \\
(0.0103)\end{array}$ & $\begin{array}{l}-0.0437 * * * \\
(0.0107)\end{array}$ \\
\hline$D S U C$ & $\begin{array}{l}-0.000898 \\
(0.00175)\end{array}$ & $\begin{array}{l}0.00144 \\
(0.00403)\end{array}$ & $\begin{array}{l}-0.00523 \\
(0.00593)\end{array}$ & $\begin{array}{l}-0.00744 \\
(0.00747)\end{array}$ \\
\hline LOSPRY & $\begin{array}{l}-0.00888^{* * *} \\
(0.00108)\end{array}$ & $\begin{array}{l}-0.00897 * * * \\
(0.00318)\end{array}$ & $\begin{array}{l}-0.00351 \\
(0.00389)\end{array}$ & $\begin{array}{l}-0.0244 * * * \\
(0.00499)\end{array}$ \\
\hline Constant & $\begin{array}{l}0.0243 * * * \\
(0.00341)\end{array}$ & $\begin{array}{l}0.00554 \\
(0.00694)\end{array}$ & $\begin{array}{l}0.0500 * * * \\
(0.0106)\end{array}$ & $\begin{array}{l}0.0830 * * * \\
(0.0125)\end{array}$ \\
\hline Observations & 6558 & 5630 & 5892 & 5138 \\
\hline Number of firms & 3358 & 2956 & 2962 & 2647 \\
\hline$Y E A R$ & Yes & Yes & Yes & Yes \\
\hline Firm fixed effects & Yes & Yes & Yes & Yes \\
\hline R-sq overall & $0.8629 * * *$ & $0.6864 * * *$ & $0.1945^{* * *}$ & $0.1753 * * *$ \\
\hline
\end{tabular}

Robust standard errors in parentheses

$* * * p<0.01, * * p<0.05, * p<0.1$ 
Table 7 Fama-MacBeth estimations for CGS, LC and OTHOP for the full and propensity score-matched samples

\begin{tabular}{|c|c|c|c|c|c|c|}
\hline \multirow[t]{3}{*}{ Variables } & (1) & (2) & (3) & (4) & (5) & $(6)$ \\
\hline & \multicolumn{3}{|l|}{ Full sample } & \multicolumn{3}{|c|}{ Propensity score-matched sample } \\
\hline & $\Delta \log C G S$ & $\Delta \log L C$ & $\triangle \log O T H O P$ & $\Delta \log C G S$ & $\Delta \log L C$ & $\triangle \log O T H O P$ \\
\hline$\Delta \log R E V$ & $\begin{array}{l}0.997 * * * \\
(0.00530)\end{array}$ & $\begin{array}{l}0.770 * * * \\
(0.0154)\end{array}$ & $\begin{array}{l}0.803 * * * \\
(0.00795)\end{array}$ & $\begin{array}{l}0.993 * * * \\
(0.0245)\end{array}$ & $\begin{array}{l}0.720 * * * \\
(0.0189)\end{array}$ & $\begin{array}{l}0.802 * * * \\
(0.0430)\end{array}$ \\
\hline$D \cdot \Delta \log R E V$ & $\begin{array}{l}0.0705 * * \\
(0.0205)\end{array}$ & $\begin{array}{l}-0.400^{* * *} \\
(0.0573)\end{array}$ & $\begin{array}{l}-0.299 * * * \\
(0.0390)\end{array}$ & $\begin{array}{l}0.0853 \\
(0.0601)\end{array}$ & $\begin{array}{l}-0.385^{*} \\
(0.166)\end{array}$ & $\begin{array}{l}-0.444^{*} \\
(0.192)\end{array}$ \\
\hline$D \cdot \triangle \log R E V \cdot E C O M$ & $\begin{array}{l}0.0197 \\
(0.0287)\end{array}$ & $\begin{array}{l}-0.0714 \\
(0.0906)\end{array}$ & $\begin{array}{l}0.193 * * * \\
(0.0495)\end{array}$ & $\begin{array}{l}0.00166 \\
(0.0542)\end{array}$ & $\begin{array}{l}0.0966 \\
(0.142)\end{array}$ & $\begin{array}{l}0.194 * * \\
(0.0645)\end{array}$ \\
\hline$D \cdot \Delta \log R E V \cdot E M P L I N T$ & $\begin{array}{l}-0.288 \\
(0.203)\end{array}$ & $\begin{array}{l}2.334 * * \\
(0.777)\end{array}$ & $\begin{array}{l}1.707 \\
(1.385)\end{array}$ & $\begin{array}{l}3.854 \\
(3.483)\end{array}$ & $\begin{array}{l}-1.624 \\
(4.522)\end{array}$ & $\begin{array}{l}28.54 \\
(16.62)\end{array}$ \\
\hline$D \cdot \Delta \log R E V \cdot A S S I N T$ & $\begin{array}{l}-0.0288^{* * *} \\
(0.00407)\end{array}$ & $\begin{array}{l}-0.0285^{* * *} \\
(0.00585)\end{array}$ & $\begin{array}{l}-0.0280 * * * \\
(0.00775)\end{array}$ & $\begin{array}{l}0.0101 \\
(0.0279)\end{array}$ & $\begin{array}{l}-0.0579 \\
(0.0478)\end{array}$ & $\begin{array}{l}0.0403^{*} \\
(0.0204)\end{array}$ \\
\hline$D \cdot \triangle \log R E V \cdot R O A$ & $\begin{array}{l}0.176^{*} \\
(0.0820)\end{array}$ & $\begin{array}{l}0.180 \\
(0.0950)\end{array}$ & $\begin{array}{l}0.641 * * * \\
(0.101)\end{array}$ & $\begin{array}{l}0.250 \\
(0.240)\end{array}$ & $\begin{array}{l}0.0911 \\
(0.224)\end{array}$ & $\begin{array}{l}-0.137 \\
(0.182)\end{array}$ \\
\hline$D \cdot \triangle \log R E V \cdot D E B T T A$ & $\begin{array}{l}-0.0127 \\
(0.0164)\end{array}$ & $\begin{array}{l}0.0203 \\
(0.0446)\end{array}$ & $\begin{array}{l}0.116^{* *} \\
(0.0456)\end{array}$ & $\begin{array}{l}0.00365 \\
(0.0367)\end{array}$ & $\begin{array}{l}-0.235 \\
(0.213)\end{array}$ & $\begin{array}{l}-0.0257 \\
(0.187)\end{array}$ \\
\hline$D \cdot \Delta \log R E V \cdot D S U C$ & $\begin{array}{l}0.0310^{*} \\
(0.0146)\end{array}$ & $\begin{array}{l}0.177 * * * \\
(0.0426)\end{array}$ & $\begin{array}{l}0.0295 \\
(0.0353)\end{array}$ & $\begin{array}{l}-0.00626 \\
(0.0341)\end{array}$ & $\begin{array}{l}0.309 * * * \\
(0.0822)\end{array}$ & $\begin{array}{l}0.00363 \\
(0.186)\end{array}$ \\
\hline$D \cdot \triangle \log R E V \cdot L O S P R Y$ & $\begin{array}{l}0.0217 * \\
(0.0111)\end{array}$ & $\begin{array}{l}0.0371 * * \\
(0.0141)\end{array}$ & $\begin{array}{l}0.149 * * \\
(0.0486)\end{array}$ & $\begin{array}{l}-0.0423 \\
(0.0604)\end{array}$ & $\begin{array}{l}0.116 \\
(0.117)\end{array}$ & $\begin{array}{l}0.128 \\
(0.118)\end{array}$ \\
\hline ECOM & $\begin{array}{l}-2.62 \mathrm{e}-05 \\
(0.000810)\end{array}$ & $\begin{array}{l}-0.00130 \\
(0.00165)\end{array}$ & $\begin{array}{l}0.00460 * * * \\
(0.000939)\end{array}$ & $\begin{array}{l}-0.00105 \\
(0.00156)\end{array}$ & $\begin{array}{l}0.00324 * \\
(0.00143)\end{array}$ & $\begin{array}{l}0.00507 * \\
(0.00232)\end{array}$ \\
\hline EMPLINT & $\begin{array}{l}-0.0615^{* *} \\
(0.0179)\end{array}$ & $\begin{array}{l}0.278 \\
(0.166)\end{array}$ & $\begin{array}{l}0.0179 \\
(0.0886)\end{array}$ & $\begin{array}{l}-0.129 \\
(0.257)\end{array}$ & $\begin{array}{l}0.809 * * * \\
(0.159)\end{array}$ & $\begin{array}{l}0.435^{*} \\
(0.224)\end{array}$ \\
\hline$A S S I N T$ & $\begin{array}{l}-0.00166^{* * * *} \\
(0.000386)\end{array}$ & $\begin{array}{l}-0.00220 * * * \\
(0.000395)\end{array}$ & $\begin{array}{l}-0.00110 * * * \\
(0.000262)\end{array}$ & $\begin{array}{l}0.00115 \\
(0.00162)\end{array}$ & $\begin{array}{l}-0.00169 \\
(0.00124)\end{array}$ & $\begin{array}{l}-0.00151 \\
(0.00140)\end{array}$ \\
\hline$R O A$ & $\begin{array}{l}-0.0241 * * * \\
(0.00267)\end{array}$ & $\begin{array}{l}-0.00386 \\
(0.00218)\end{array}$ & $\begin{array}{l}-0.0839 * * * \\
(0.00307)\end{array}$ & $\begin{array}{l}-0.0236^{* * *} \\
(0.00651)\end{array}$ & $\begin{array}{l}-0.0105 \\
(0.0101)\end{array}$ & $\begin{array}{l}-0.0852 * * * \\
(0.00899)\end{array}$ \\
\hline DEBTTA & $\begin{array}{l}-0.00182 * * * \\
(0.000242)\end{array}$ & $\begin{array}{l}-0.00507 * * * \\
(0.00101)\end{array}$ & $\begin{array}{l}-0.00871^{* *} \\
(0.00252)\end{array}$ & $\begin{array}{l}-0.00156 \\
(0.00173)\end{array}$ & $\begin{array}{l}-0.0125 * * * \\
(0.00285)\end{array}$ & $\begin{array}{l}-0.0176^{* * * *} \\
(0.00483)\end{array}$ \\
\hline DSUC & $\begin{array}{l}0.00100 * * \\
(0.000411)\end{array}$ & $\begin{array}{l}-0.00386^{* *} \\
(0.00141)\end{array}$ & $\begin{array}{l}-0.00225 \\
(0.00122)\end{array}$ & $\begin{array}{l}0.000965 \\
(0.00109)\end{array}$ & $\begin{array}{l}-0.00255 \\
(0.00232)\end{array}$ & $\begin{array}{l}-0.0105^{* * *} \\
(0.00287)\end{array}$ \\
\hline LOSPRY & $\begin{array}{l}-0.00358 * * * \\
(0.000663)\end{array}$ & $\begin{array}{l}-0.00416^{* * *} \\
(0.00116)\end{array}$ & $\begin{array}{l}-0.0140^{\text {*** }} \\
(0.00243)\end{array}$ & $\begin{array}{l}-0.00536^{* *} \\
(0.00158)\end{array}$ & $\begin{array}{l}-0.00474 \\
(0.00307)\end{array}$ & $\begin{array}{l}-0.0160 * * * \\
(0.00263)\end{array}$ \\
\hline Constant & $\begin{array}{l}0.00358 * * * \\
(0.000277)\end{array}$ & $\begin{array}{l}0.0123 * * * \\
(0.00176)\end{array}$ & $\begin{array}{l}0.0179 * * * \\
(0.00180)\end{array}$ & $\begin{array}{l}0.00383 \\
(0.00242)\end{array}$ & $\begin{array}{l}0.0139 * * * \\
(0.00263)\end{array}$ & $\begin{array}{l}0.0235^{* * * *} \\
(0.00390)\end{array}$ \\
\hline Observations & 75,174 & 69,828 & 64,108 & 5630 & 5892 & 5138 \\
\hline $\begin{array}{l}\text { Number of groups } \\
\text { (years) }\end{array}$ & 8 & 8 & 8 & 8 & 8 & 8 \\
\hline Average R-sq & $0.7750 * * *$ & $0.3168 * * *$ & $0.2274 * * *$ & $0.7445 * * *$ & $0.2695 * * *$ & $0.2734 * * *$ \\
\hline
\end{tabular}

Standard errors in parentheses

${ }^{* * *} p<0.01, * * p<0.05, * p<0.1$ 
legislation (EPL). Banker et al. [68] find that costs associated with firing workers, measured through the OECD indicators of EPL, are associated with cost stickiness. Golden et al. [69] find that the share of skilled labor is associated with greater operating cost asymmetry, and assume that this is caused by the higher costs of firing, searching and selection of skilled versus non-skilled employees. Dierynck et al. [26] find differences between the LC behavior of blue- and white-collar employees, which they attribute to the differences in their dismissal costs. Prabowo et al. [29] find a positive relationship between stringent labor dismissal and LC stickiness, also using OECD country-level indicators of labor dismissal.

Addressing these previous concerns, in order to relieve endogeneity issues due to omitted variables, which may bias our results for LC, we conduct additional analyses including variables about different types of employees and country level of employment protection. We approach these through LC per employee ( $L C N E M P L)$ and the available $E P L$ scores of the different countries and years on the OECD website, ${ }^{1}$ variable $E P L$. Higher $E P L$ values mean more stringent labor laws and, therefore, higher levels of protection and lower levels of firm flexibility. We include these standalone variables, and the corresponding interactions to assess their specific influence in LC stickiness $(D \cdot \Delta \log R E V \cdot L C N E M P L$ and $D \cdot \Delta \log R E V \cdot E P L)$, and the influence of e-commerce in this specific stickiness $(D \cdot \Delta \log R E V \cdot L C N E M P L \cdot E C O M$ and $D \cdot \triangle \log R E V \cdot E P L \cdot E C O M)$.

Table 8 shows the results of the corresponding estimations for the whole and propensity score-matched samples. The number of observations is slightly lower than in previous tables because of the lack of EPL scores for some countries and years. The coefficients of the standalone variables display positive and significant signs for $L C N E M P L$ in all cases and negative signs for $E P L$, and significant for the full sample. The negative coefficients of the interaction variables $D \cdot \triangle \log R E V \cdot L C N E M P L$ and $D \cdot \Delta \log R E V \cdot E P L$ are also negative in all cases, as expected and in line with previous studies (higher stickiness for highest salaries and for more protective labor legislations), but significant only for the full sample. The important point for the purpose of our study is that e-commerce does not significantly affect the stickiness of labor costs, neither controlling for these factors nor moderating or stressing the sticky influence of these factors. Again, our results fail to provide support for $\mathrm{H} 2$ when the dependent variable is $L C$.

As mentioned, the descriptive statistics in Table 2 reveal that traditional retail firms bear lower labor costs per employee. These employees are exposed to higher risk of being dismissed, because the costs associated with firing are lower. Consequently, the labor cost stickiness of traditional firms should be higher. The similar pattern exhibited by e-commerce and traditional firms in our results may be indirect evidence of a different relationship influenced by e-commerce, but hindered by these biased characteristics in our sample. To rule out this possibility, we split the sample into labor costs per employee above and below the median and, once again, the

\footnotetext{
1 See https://www.oecd.org/employment/emp/oecdindicatorsofemploymentprotection.htm for data and http://www.oecd.org/employment/emp/38940931.pdf for details on the methodology and aggregated scores.
} 
Table 8 Fixed-effects estimations for LC including controls for EPL and LCNEMPL in Eq. 1. Year and country-year fixed effects

\begin{tabular}{|c|c|c|c|c|}
\hline Variables & $\begin{array}{l}\text { (1) } \\
\text { Full sample }\end{array}$ & $\begin{array}{l}\text { (2) } \\
\text { Propensity score- } \\
\text { matched sample }\end{array}$ & $\begin{array}{l}\text { (3) } \\
\text { Full sample }\end{array}$ & $\begin{array}{l}\text { (4) } \\
\text { Propensity } \\
\text { score-matched } \\
\text { sample }\end{array}$ \\
\hline$\Delta \log R E V$ & $\begin{array}{l}0.633 * * * \\
(0.0115)\end{array}$ & $\begin{array}{l}0.538 * * * \\
(0.0470)\end{array}$ & $\begin{array}{l}0.633 * * * \\
(0.0115)\end{array}$ & $\begin{array}{l}0.536 * * * \\
(0.0470)\end{array}$ \\
\hline$D \cdot \Delta \log R E V$ & $\begin{array}{l}0.0707 \\
(0.0831)\end{array}$ & $\begin{array}{l}0.658 \\
(0.499)\end{array}$ & $\begin{array}{l}0.0687 \\
(0.0831)\end{array}$ & $\begin{array}{l}0.659 \\
(0.502)\end{array}$ \\
\hline$D \cdot \Delta \log R E V \cdot E C O M$ & $\begin{array}{l}-0.372 \\
(0.246)\end{array}$ & $\begin{array}{l}-0.485 \\
(0.544)\end{array}$ & $\begin{array}{l}-0.371 \\
(0.246)\end{array}$ & $\begin{array}{l}-0.503 \\
(0.546)\end{array}$ \\
\hline$D \cdot \Delta \log R E V \cdot E P L$ & $\begin{array}{l}-0.121 * * * \\
(0.0294)\end{array}$ & $\begin{array}{l}-0.219 \\
(0.165)\end{array}$ & $\begin{array}{l}-0.120^{* * *} \\
(0.0294)\end{array}$ & $\begin{array}{l}-0.217 \\
(0.165)\end{array}$ \\
\hline$D \cdot \Delta \log R E V \cdot E P L \cdot E C O M$ & $\begin{array}{l}0.148 \\
(0.123)\end{array}$ & $\begin{array}{l}0.219 \\
(0.198)\end{array}$ & $\begin{array}{l}0.149 \\
(0.123)\end{array}$ & $\begin{array}{l}0.223 \\
(0.198)\end{array}$ \\
\hline$D \cdot \triangle \log R E V \cdot L C N E M P L$ & $\begin{array}{l}-0.00269^{* *} \\
(0.00126)\end{array}$ & $\begin{array}{l}-0.00750 \\
(0.00679)\end{array}$ & $\begin{array}{l}-0.00267^{* *} \\
(0.00126)\end{array}$ & $\begin{array}{l}-0.00773 \\
(0.00686)\end{array}$ \\
\hline$D \cdot \Delta \log R E V \cdot L C N E M P L \cdot E C O M$ & $\begin{array}{l}0.00108 \\
(0.00397)\end{array}$ & $\begin{array}{l}0.00311 \\
(0.00786)\end{array}$ & $\begin{array}{l}0.00102 \\
(0.00396)\end{array}$ & $\begin{array}{l}0.00327 \\
(0.00792)\end{array}$ \\
\hline$D \cdot \Delta \log R E V \cdot E M P L I N T$ & $\begin{array}{l}11.06 * * * \\
(2.972)\end{array}$ & $\begin{array}{l}-40.86 \\
(27.41)\end{array}$ & $\begin{array}{l}11.10^{* * * *} \\
(2.976)\end{array}$ & $\begin{array}{l}-40.85 \\
(27.51)\end{array}$ \\
\hline$D \cdot \Delta \log R E V \cdot A S S I N T$ & $\begin{array}{l}-0.0165 \\
(0.0109)\end{array}$ & $\begin{array}{l}-0.0196 \\
(0.0520)\end{array}$ & $\begin{array}{l}-0.0165 \\
(0.0109)\end{array}$ & $\begin{array}{l}-0.0179 \\
(0.0518)\end{array}$ \\
\hline$D \cdot \Delta \log R E V \cdot R O A$ & $\begin{array}{l}0.244 * * \\
(0.102)\end{array}$ & $\begin{array}{l}0.0766 \\
(0.303)\end{array}$ & $\begin{array}{l}0.242 * * \\
(0.102)\end{array}$ & $\begin{array}{l}0.0711 \\
(0.307)\end{array}$ \\
\hline$D \cdot \Delta \log R E V \cdot D E B T T A$ & $\begin{array}{l}0.0636 \\
(0.0389)\end{array}$ & $\begin{array}{l}0.0517 \\
(0.140)\end{array}$ & $\begin{array}{l}0.0615 \\
(0.0389)\end{array}$ & $\begin{array}{l}0.0589 \\
(0.140)\end{array}$ \\
\hline$D \cdot \Delta \log R E V \cdot D S U C$ & $\begin{array}{l}0.121 * * * \\
(0.0363)\end{array}$ & $\begin{array}{l}0.0754 \\
(0.156)\end{array}$ & $\begin{array}{l}0.121 * * * \\
(0.0363)\end{array}$ & $\begin{array}{l}0.0672 \\
(0.155)\end{array}$ \\
\hline$D \cdot \Delta \log R E V \cdot L O S P R Y$ & $\begin{array}{l}0.0229 \\
(0.0348)\end{array}$ & $\begin{array}{l}0.0841 \\
(0.147)\end{array}$ & $\begin{array}{l}0.0226 \\
(0.0348)\end{array}$ & $\begin{array}{l}0.0945 \\
(0.148)\end{array}$ \\
\hline$E P L$ & $\begin{array}{l}-0.00835^{* * * *} \\
(0.00218)\end{array}$ & $\begin{array}{l}-0.00359 \\
(0.0119)\end{array}$ & $\begin{array}{l}-0.00705^{* * * *} \\
(0.00221)\end{array}$ & $\begin{array}{l}-0.00323 \\
(0.0120)\end{array}$ \\
\hline$L C N E M P L$ & $\begin{array}{l}0.000948^{* * * *} \\
(8.54 \mathrm{e}-05)\end{array}$ & $\begin{array}{l}0.00145^{* * * *} \\
(0.000312)\end{array}$ & $\begin{array}{l}0.000949 * * * \\
(8.52 \mathrm{e}-05)\end{array}$ & $\begin{array}{l}0.00143 * * * \\
(0.000310)\end{array}$ \\
\hline EMPLINT & $\begin{array}{l}1.102^{* * *} \\
(0.322)\end{array}$ & $\begin{array}{l}2.419 * * * \\
(0.765)\end{array}$ & $\begin{array}{l}1.095^{* * *} \\
(0.321)\end{array}$ & $\begin{array}{l}2.348 * * * \\
(0.773)\end{array}$ \\
\hline ASSINT & $\begin{array}{l}-0.00123 \\
(0.00118)\end{array}$ & $\begin{array}{l}-0.00240 \\
(0.00294)\end{array}$ & $\begin{array}{l}-0.00128 \\
(0.00118)\end{array}$ & $\begin{array}{l}-0.00231 \\
(0.00294)\end{array}$ \\
\hline$R O A$ & $\begin{array}{l}-0.0418 * * * \\
(0.00502)\end{array}$ & $\begin{array}{l}-0.0505^{* * *} \\
(0.0186)\end{array}$ & $\begin{array}{l}-0.0426^{* * *} \\
(0.00503)\end{array}$ & $\begin{array}{l}-0.0500^{* * * *} \\
(0.0188)\end{array}$ \\
\hline DEBTTA & $\begin{array}{l}-0.0139 * * * \\
(0.00277)\end{array}$ & $\begin{array}{l}-0.0229^{* *} \\
(0.00975)\end{array}$ & $\begin{array}{l}-0.0140^{* * *} \\
(0.00277)\end{array}$ & $\begin{array}{l}-0.0227 * * \\
(0.00979)\end{array}$ \\
\hline DSUC & -0.000799 & -0.00723 & -0.000747 & -0.00725 \\
\hline
\end{tabular}


Table 8 (continued)

\begin{tabular}{|c|c|c|c|c|}
\hline \multirow[t]{3}{*}{ Variables } & (1) & (2) & (3) & (4) \\
\hline & Full sample & $\begin{array}{l}\text { Propensity score- } \\
\text { matched sample }\end{array}$ & Full sample & $\begin{array}{l}\text { Propensity } \\
\text { score-matched } \\
\text { sample }\end{array}$ \\
\hline & $(0.000970)$ & $(0.00636)$ & $(0.000970)$ & $(0.00636)$ \\
\hline \multirow[t]{2}{*}{$L O S P R Y$} & $-0.00370 * * *$ & -0.00177 & $-0.00381 * * *$ & -0.00195 \\
\hline & $(0.000777)$ & (0.00399) & $(0.000776)$ & $(0.00400)$ \\
\hline \multirow[t]{2}{*}{ Constant } & $0.0115^{*}$ & -0.00587 & 0.00866 & -0.00551 \\
\hline & $(0.00675)$ & $(0.0306)$ & $(0.00679)$ & $(0.0306)$ \\
\hline Observations & 60,926 & 5474 & 60,926 & 5474 \\
\hline Number of firms & 11,730 & 2747 & 11,730 & 2747 \\
\hline$Y E A R$ & Yes & Yes & & \\
\hline Country-Year fixed effects & & & Yes & Yes \\
\hline Firm fixed effects & Yes & Yes & Yes & Yes \\
\hline R-sq overall & $0.2192 * * *$ & $0.1287 * * *$ & $0.2229 * * *$ & $0.1303 * * *$ \\
\hline
\end{tabular}

Robust standard errors in parentheses

$* * * p<0.01, * * p<0.05, * p<0.1$

results (not tabulated for the purposes of simplicity) provide no significant signs for the coefficients of our experimental variable, reinforcing the previous results indicating no influence of e-commerce in the asymmetric behavior of labor costs.

\section{Discussion and conclusions}

This study analyzes the relationship between e-commerce and asymmetric cost behavior, using an international sample of European retail firms. We find no specific influence of e-commerce on CGS, as hypothesized in H1, given that they are automatically recorded in the profit and loss statement, independently of the type of business. They display slightly anti-sticky behavior, probably caused by a different product mix or lower acquisition costs in periods of decreasing sales. However, we find no differences in the asymmetric cost behavior between e-commerce and traditional retail firms.

Our results show empirical evidence of more flexible OTHOP behavior in e-commerce firms than in traditional retail firms. The former apply greater cuts in OTHOP than traditional firms do when activity decreases. Along the same lines, e-commerce firms seem to be more capable of adjusting resources in unfavorable conditions, which is probably part of a wider ability to adapt to new circumstances. E-commerce is a recent form of business that, in its inception, is knowledge based. The internet environment in which e-commerce is conducted is fully involved in recording and generating information. It is agile in producing information on business development and requiring urgent feedback and responses. It is also technology based. The obsolescence risks involved in terms of technology requirements and business 
setting are more demanding in e-commerce than in traditional business. Altogether, this generates a more dynamic pace to adapt to new circumstances, which, in turn, accelerates the speed of pragmatic resource adjustment. Our empirical evidence suggests more flexible use of other operational resources in e-commerce than in traditional firms. E-commerce is not only a different business model, but also a more flexible way of doing business, that adds greater economic efficiency.

We find no empirical evidence of differences in the asymmetric behavior of LC. Contrary to expectations, e-commerce firms do not exhibit higher cuts in labor costs when activity decreases than traditional retail firms.

These results are robust to different estimation methods and additional analyses. They persistently show that e-commerce is a more flexible and efficient model of doing business that creates higher quality and better paid employment, which are well-known advantages of e-commerce. However, e-commerce does not affect employment stability. There is no difference in the flexibility of LC adjustment when activity decreases. There is no disadvantage of e-commerce on the side of employment precariousness. Our results do not provide evidence that e-commerce produces more negative effects for workers and employees than traditional business. The higher flexibility of e-commerce firms is based on the pool of other operating costs, which account for a substantially higher share of total operating costs in e-commerce firms in comparison to traditional retail firms. In this respect, e-commerce provides overall positive synergies to the economy and society. It creates qualified jobs with higher wages than traditional retail, and with no additional exposure to uncertainty for employees.

Previous research has distinguished advantages of brick and mortar with respect to e-commerce in many fundamental business aspects, which we have not analyzed in this study. Some authors find that e-commerce heightens the trend of precarious work, placing stress on labor control and triggering the loss of labor rights [9, 70-72] (see Panel B in the Appendix 1). Other studies find higher tax avoidance behavior of e-commerce than traditional retail firms [7, 73]. The environmental implications of e-commerce and traditional retail is controversial and the optimal balance of advantages and drawbacks of both retail channels depends on some contextual factors and cost conditions [74-76]. Moreover, Zhang et al. [77] report the following advantages of traditional retail for consumers: quality guarantee of goods, real shopping experiences such as the fitting service, exchange and return services, buy and get instantly, and problem avoidance during delivery. Therefore, despite the more flexible behavior of some operating costs in e-commerce firms, the brick-andmortar stores have their own advantages and cannot be completely displaced. The traditional retail is viable and advantageous under certain conditions, and dual channel is a plausible and optimal alternative in many cases.

The technological characteristics of e-commerce and the fact that it does not depend on physical presence generate a favorable opportunity for the use of nonstandard forms of employment, and for applying more LC cuts and discretionary 
dismissals. However, our empirical evidence suggests that e-commerce does not apply these adverse labor practices for employees. Other possible detrimental effects of e-commerce, such as for example for consumers and the environment have not been analyzed in this study, and they may deserve future analyses.

Our results have implications for scholars studying cost behavior and resource management of electronic commerce, as to the authors' knowledge it is the first to analyze the comparative resource adjustment behavior of electronic commerce versus traditional businesses. It is also of interest for practitioners, to whom it offers an assessment, grounded in empirical evidence from a big and wide sample, on the potential advantages of converting their business form traditional to e-commerce. It is also of interest for employees assessing the potential drawbacks and advantages of working in the digital versus traditional economy.

We have analyzed costs as they are registered by e-commerce firms in their accounting records, but there might be more non-standard employment recorded as non-labor costs in e-commerce than in traditional firms, which may bias our results. The topic requires future in-depth analysis of labor cost behavior and the different constituents of other operating costs in e-commerce businesses. Moreover, there is no available information on the percentage of sales performed via internet in retail firms. Most traditional retail firms also sell via the internet, but we assess the flexibility of e-commerce through a rough distinction between firms selling exclusively via the internet and other firms, which usually sell both, via internet and brick-and-mortar stores. This is an additional limitation of our research. It would be useful to perform further research using the more refined measure of the percentage of retail sales via the internet, a data that to our knowledge it is not available at firm level for a sample big enough to perform the analysis.

\section{Appendix 1}

See Table 9. 


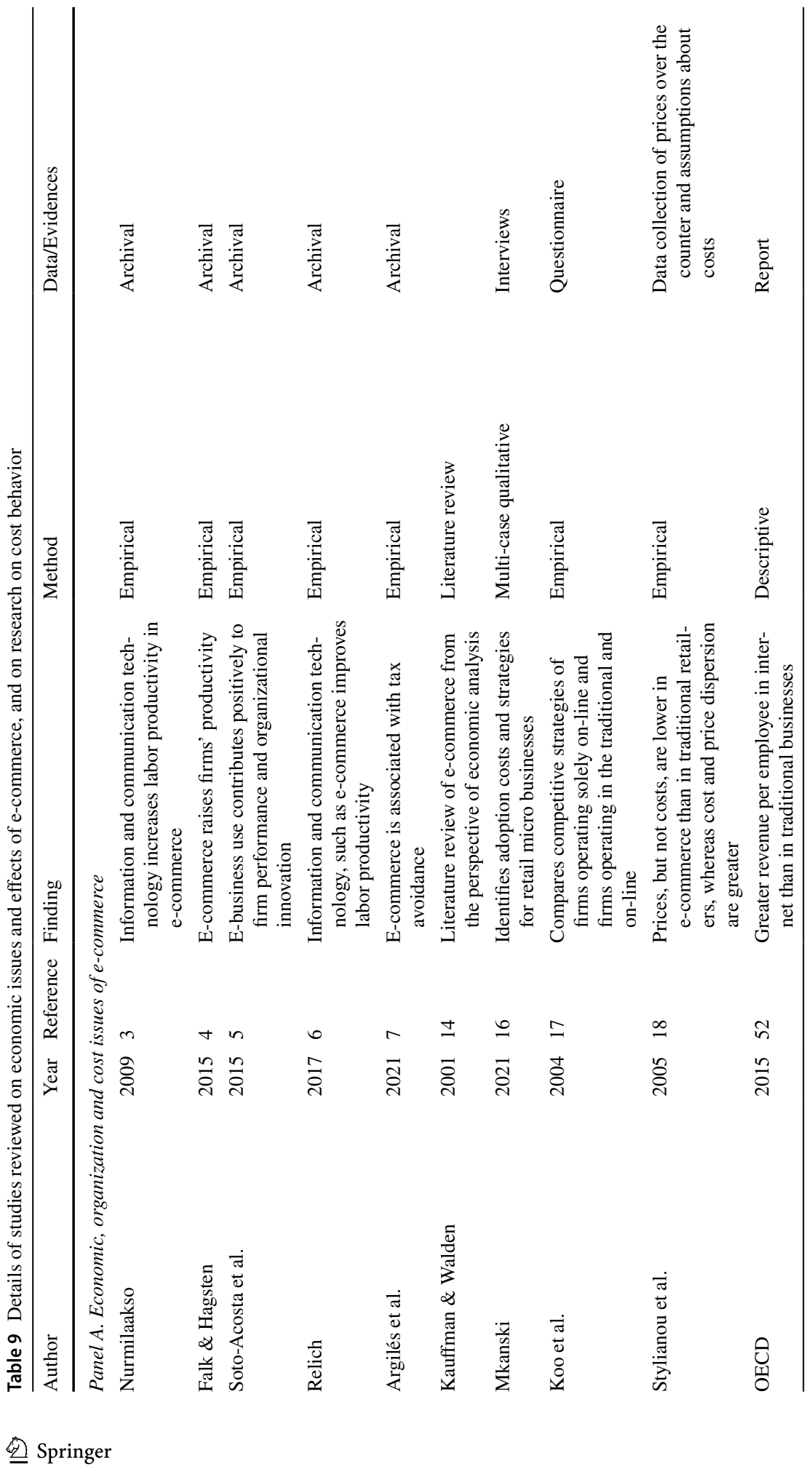




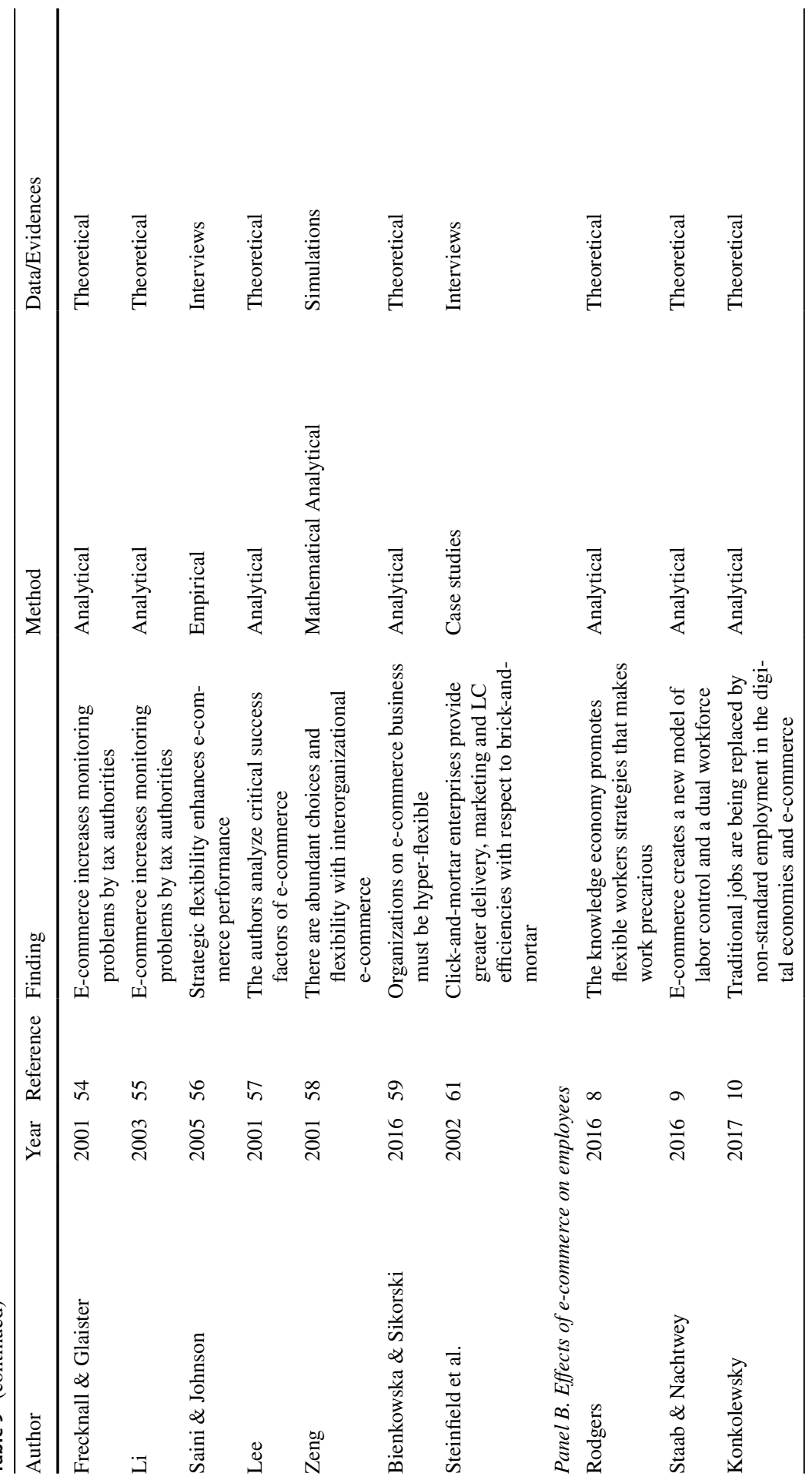




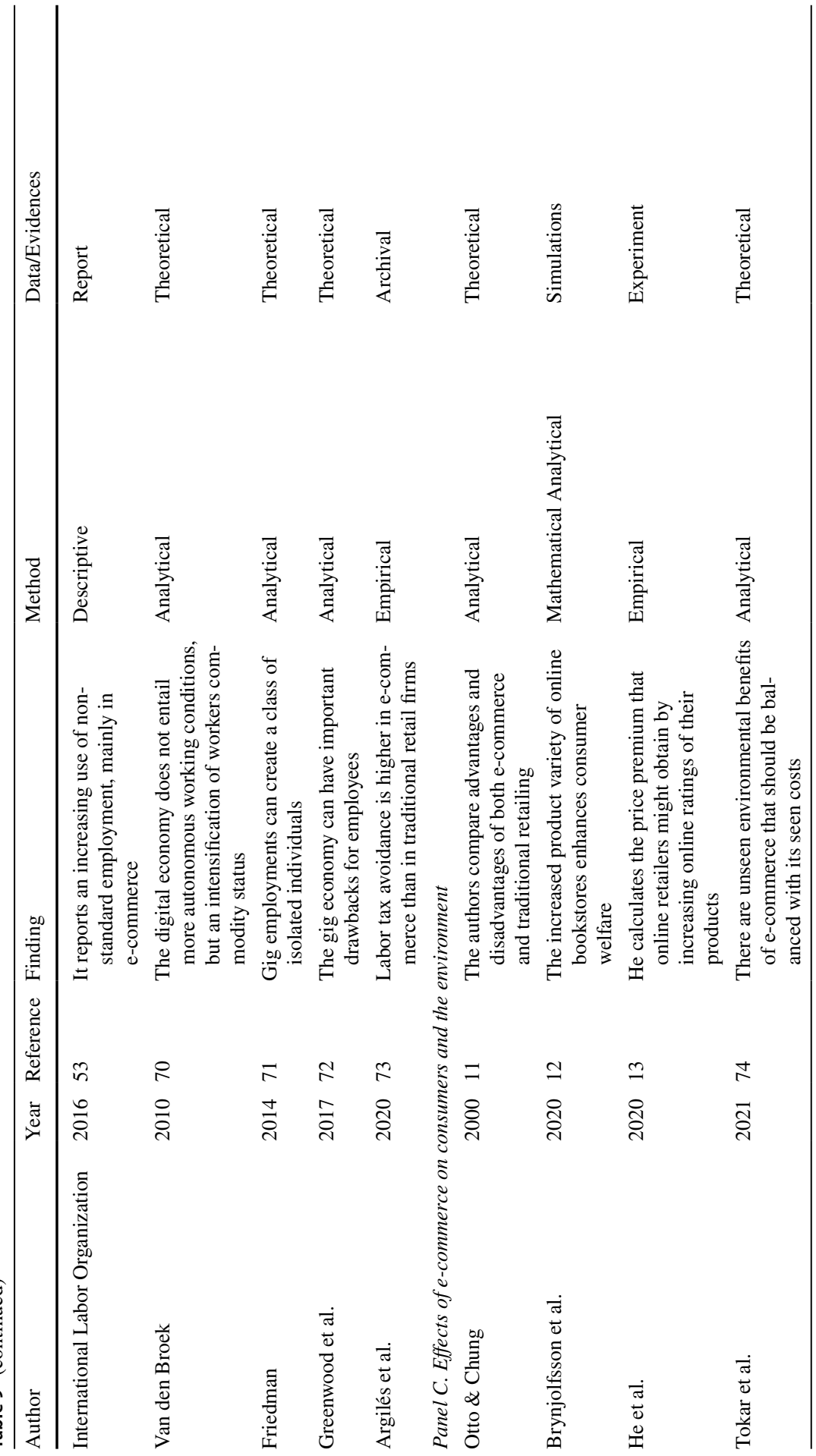




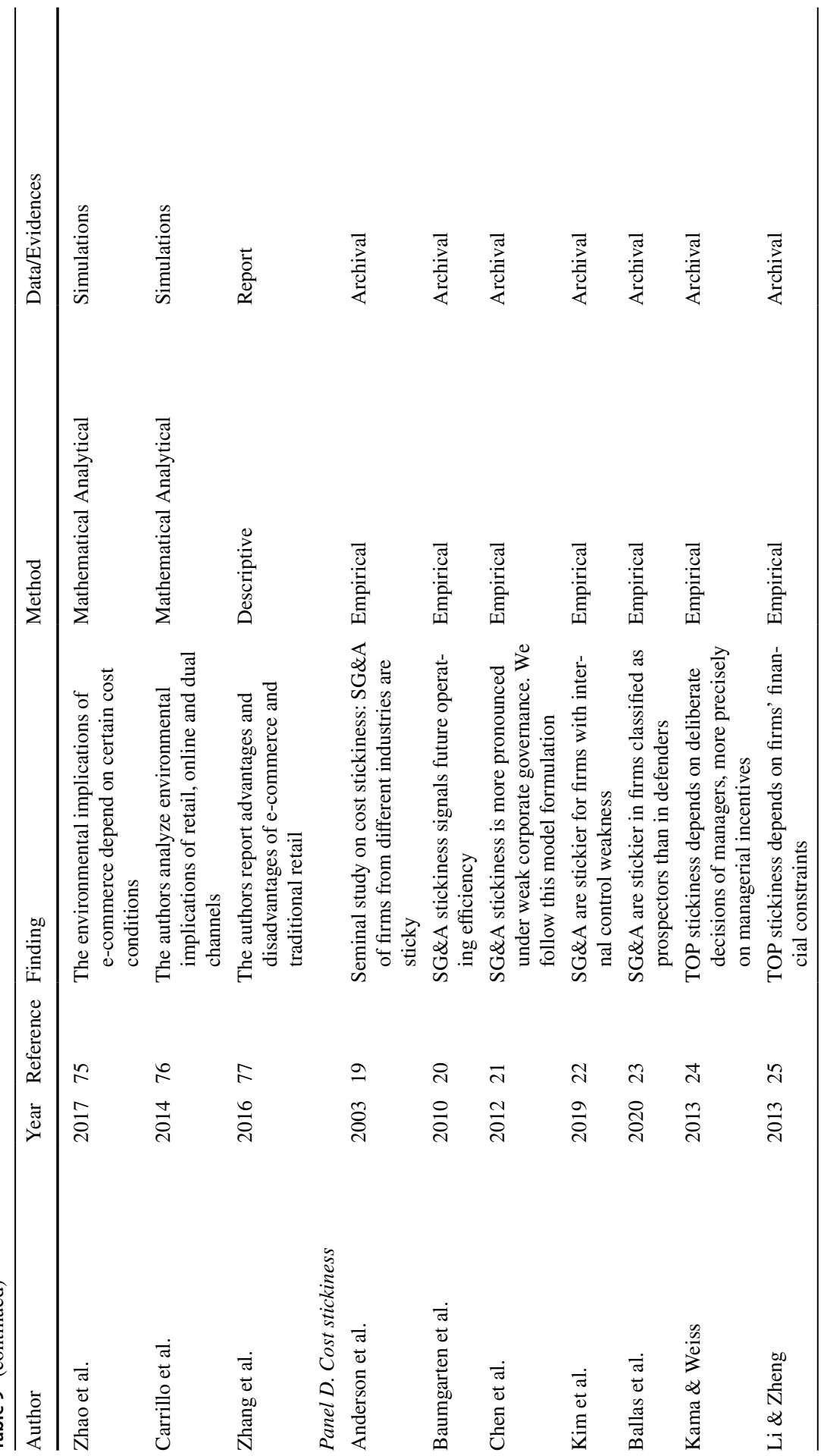




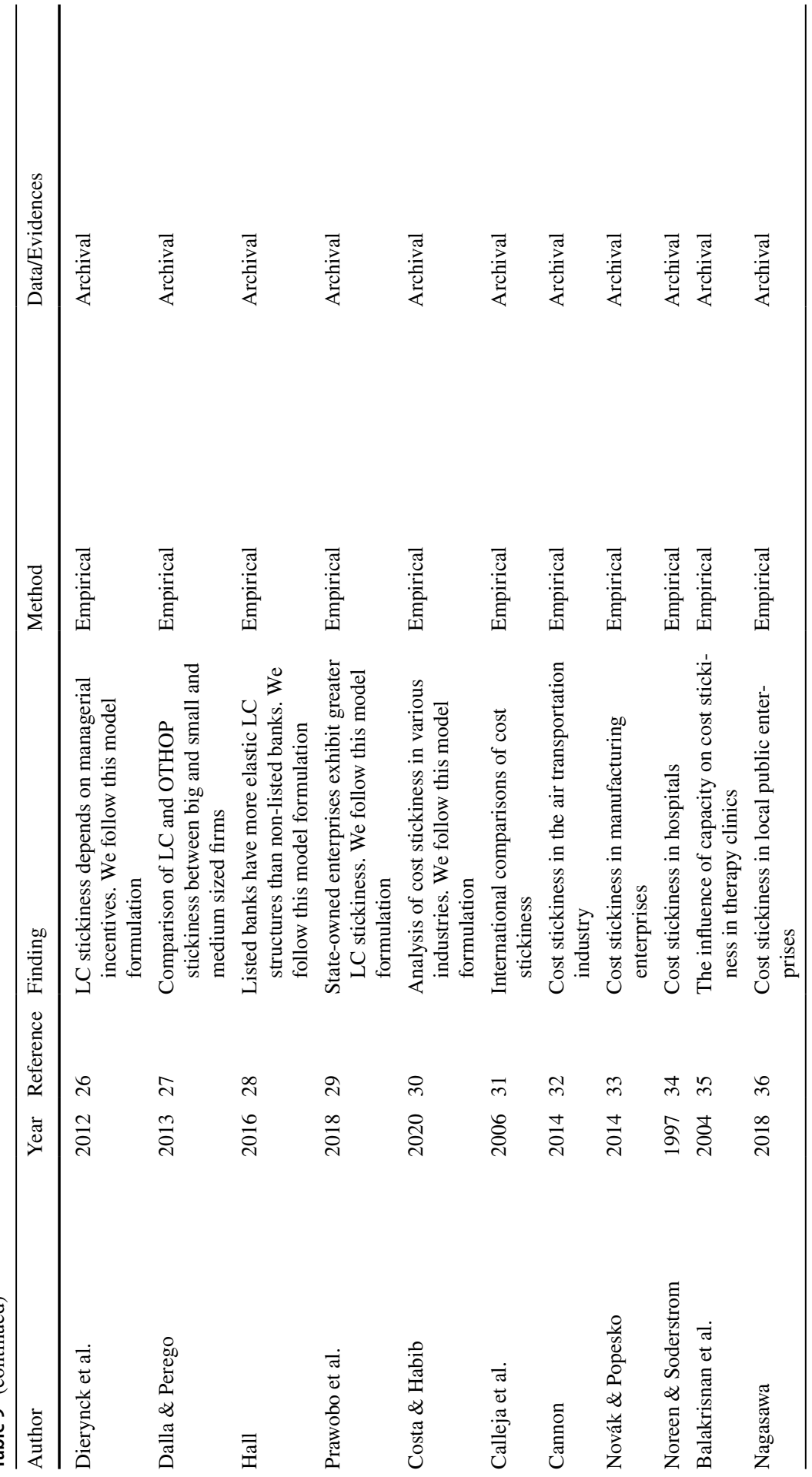




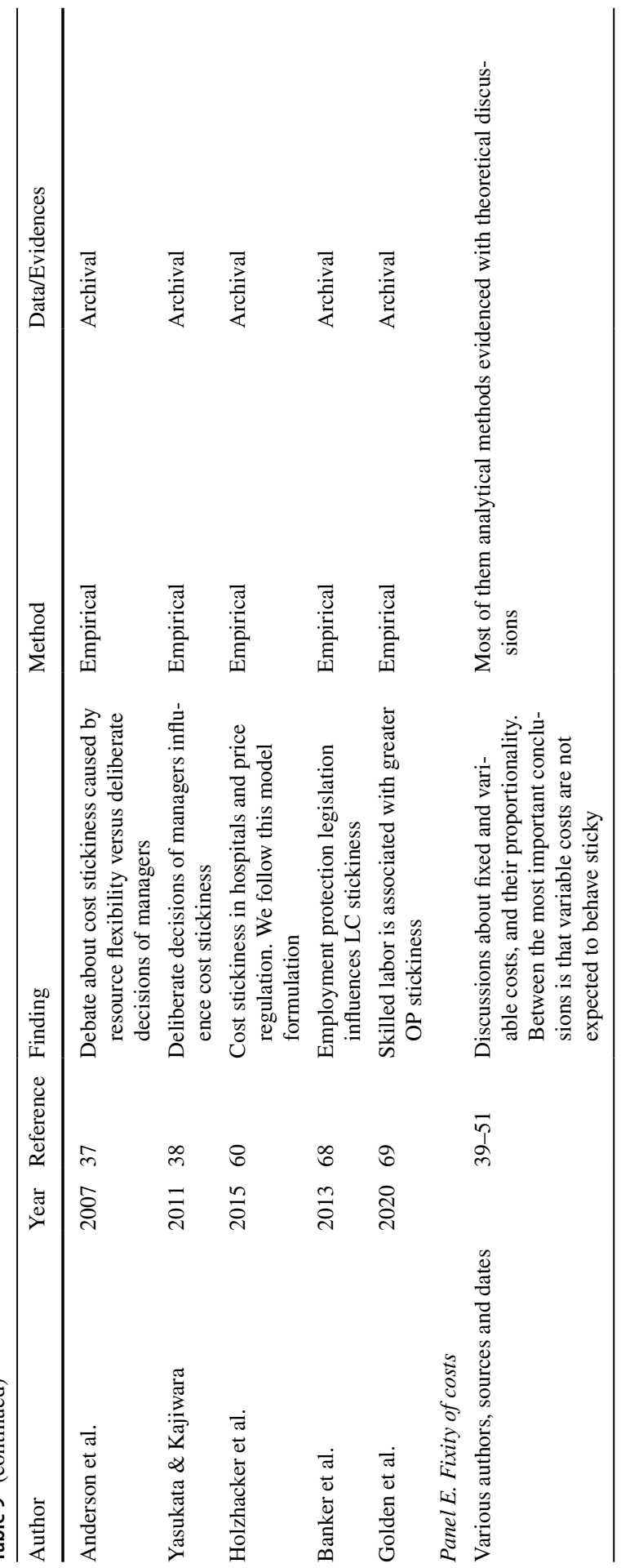




\section{Appendix 2}

See Table 10.

Table 10 Definition of variables

\begin{tabular}{|c|c|}
\hline Variable & Definition \\
\hline \multicolumn{2}{|c|}{ Dependent variables } \\
\hline$\triangle \log O P$ & Generic variable for log-change in different types of operating costs \\
\hline$\triangle \log T O P$ & $\begin{array}{l}\text { Log-change in total operating costs: logarithm of total operating costs in current } \\
\text { year divided by total operating costs in previous year }\end{array}$ \\
\hline$\Delta \log C G S$ & $\begin{array}{l}\text { Log-change in costs of goods sold: logarithm of costs of goods sold in current } \\
\text { year divided by costs of goods sold in previous year }\end{array}$ \\
\hline$\Delta \log L C$ & $\begin{array}{l}\text { Log-change in labor costs: logarithm of labor costs in current year divided by } \\
\text { labor costs in previous year }\end{array}$ \\
\hline$\triangle \log O T H O P$ & $\begin{array}{l}\text { Log-change in other operating costs (the difference between total operating costs } \\
\text { minus costs of goods sold and labor costs): logarithm of other operating costs } \\
\text { in current year divided by other operating costs in previous year }\end{array}$ \\
\hline \multicolumn{2}{|c|}{ Independent variables } \\
\hline$\Delta \log R E V$ & $\begin{array}{l}\text { log-change in revenues: logarithm of revenues in current year divided by rev- } \\
\text { enues in previous year }\end{array}$ \\
\hline$D$ & $\begin{array}{l}\text { Dummy variable equaling } 1 \text { if revenues in current year are lower than revenues } \\
\text { in previous year, and } 0 \text { otherwise }\end{array}$ \\
\hline ECOM & $\begin{array}{l}\text { Dummy variable equaling } 1 \text { if a firm is classified as performing exclusively as } \\
\text { retail trade via internet (NACE code } 4791 \text { ), and } 0 \text { otherwise (the remaining } \\
\text { NACE codes 47) }\end{array}$ \\
\hline CONTROLS & Control variables \\
\hline$E P L$ & Aggregated OECD employment protection legislation score \\
\hline$L C N E M P L$ & Labor costs divided by number of employees \\
\hline EMPLINT & Employee intensity: number of employees divided by revenues \\
\hline ASSINT & Asset intensity: total assets divided by revenues \\
\hline$R O A$ & Return on assets: operating profits divided by total assets \\
\hline DEBTTA & Indebtedness: short- and long-term debt divided by total assets \\
\hline DSUC & $\begin{array}{l}\text { Dummy variable equaling } 1 \text { for observations with two consecutive years with } \\
\text { revenues decreases, and } 0 \text { otherwise }\end{array}$ \\
\hline LOSPRY & Dummy variable equaling 1 for firms with loss in previous year, and 0 otherwise \\
\hline FIRM & Dummy variables equaling 1 for observations of a given firm, and 0 otherwise \\
\hline$Y E A R$ & Dummy variables equaling 1 for observations of a given year, and 0 otherwise \\
\hline COUNTRY & $\begin{array}{l}\text { Dummy variables equaling } 1 \text { for observations of a given country, and } 0 \text { other- } \\
\text { wise }\end{array}$ \\
\hline
\end{tabular}


Funding Open Access funding provided thanks to the CRUE-CSIC agreement with Springer Nature.

Open Access This article is licensed under a Creative Commons Attribution 4.0 International License, which permits use, sharing, adaptation, distribution and reproduction in any medium or format, as long as you give appropriate credit to the original author(s) and the source, provide a link to the Creative Commons licence, and indicate if changes were made. The images or other third party material in this article are included in the article's Creative Commons licence, unless indicated otherwise in a credit line to the material. If material is not included in the article's Creative Commons licence and your intended use is not permitted by statutory regulation or exceeds the permitted use, you will need to obtain permission directly from the copyright holder. To view a copy of this licence, visit http://creativecommons.org/licen ses/by/4.0/.

\section{References}

1. Buettner, R. (2017). Predicting user behavior in electronic markets based on personality-mining in large online social networks. A personality-based product recommender framework. Electronic Markets, 27, 247-265. https://doi.org/10.1007/s12525-016-0228-z

2. STATISTA. (2021). E-commerce worldwide. Statista. Retrieved from https://www-statista-com. sire.ub.edu/study/10653/e-commerce-worldwide-statista-dossier/

3. Nurmilaakso, J. M. (2009). ICT solutions and labor productivity: Evidence from firm-level data. Electronic Commerce Research, 9(3), 173-181. https://doi.org/10.1007/s10660-009-9034-4

4. Falk, M., \& Hagsten, E. (2015). E-commerce trends and impacts across Europe. International Journal of Production Economics, 170, 357-369. https://doi.org/10.1016/j.ijpe.2015.10.003

5. Soto-Acosta, P., Popa, S., \& Palacios-Marqués, D. (2015). E-Business, organizational innovation and firm performance in manufacturing smes: An empirical study in Spain. Technological and Economic Development of Economy, 22(6), 885-904. https://doi.org/10.3846/20294913.2015.1074126

6. Relich, M. (2017). The impact of ICT on labor productivity in the EU. Information Technology for Development, 23(4), 706-722. https://doi.org/10.1080/02681102.2017.1336071

7. Argilés-Bosch, J. M., Somoza, A., Ravenda, D., \& García-Blandón, J. (2020). An empirical examination of the influence of e-commerce on tax avoidance in Europe. Journal of International Accounting, Auditing and Taxation, 41(100339), 1-16. https://doi.org/10.1016/j.intaccaudtax.2020. 100339

8. Rodgers, L. (2016). Labour law, vulnerability and the regulation of precarious work. Edward Elgar.

9. Staab, P., \& Nachtwey, O. (2016). Market and labour control in digital capitalism. TripleC, 14(2), 457-474.

10. Konkolewsky, H.-H. (2017). Digital economy and the future of social security. Administration, 65(4), 21-30. https://doi.org/10.1515/admin-2017-0031

11. Otto, J. R., \& Chung, Q. B. (2000). A framework for cyber-enhanced retailing: Integrating e-commerce retailing with brick-and-mortar retailing. Electronic Markets, 10(3), 185-191. https://doi.org/ 10.1080/10196780050177099

12. Brynjolfsson, E., Hu, Y. J., \& Smith, M. D. (2003). Consumer surplus in the digital economy: Estimating the value of increased product variety at online booksellers. Management Science, 49(11), 1580-1596. https://doi.org/10.2139/ssrn.400940

13. He, C., Shi, L., Gao, Z., \& House, L. (2020). The impact of customer ratings on consumer choice of fresh produce: A stated preference experiment approach. Canadian Journal of Agricultural Economics, 68(3), 359-373. https://doi.org/10.1111/cjag.12222

14. Kauffman, R. J., \& Walden, E. A. (2001). Economics and electronic commerce: survey and research directions. International Journal of Electronic Commerce, 5(4), 5-117.

15. Ongori, H., \& Migiro, S. O. (2010). Information and communication technologies adoption in SMEs: Literature review. Journal of Chinese Entrepreneurship, 2(1), 93-104. https://doi.org/10. $1108 / 17561391011019041$

16. Mkansi, M. (2021). E-business adoption costs and strategies for retail micro businesses electronic commerce research. Springer. 
17. Koo, C. M., Koh, C. E., \& Nam, K. (2004). An examination of Porter's competitive strategies in electronic virtual markets: A comparison of two on-line business models. International Journal of Electronic Commerce, 9(1), 163-180. https://doi.org/10.1080/10864415.2004.11044316

18. Stylianou, A. C., Kumar, R. L., \& Robbins, S. S. (2005). Pricing on the internet and in conventional retail channels: A study of over-the-counter pharmaceutical products. International Journal of Electronic Commerce, 10(1), 135-148. https://doi.org/10.1080/10864415.2005.11043960

19. Anderson, M. C., Banker, R. D., \& Janakiraman, S. N. (2003). Are selling, general, and administrative costs "sticky"? Journal of Accounting Research, 41(1), 47-63. https://doi.org/10.1111/1475679X.00095

20. Baumgarten, D., Bonenkamp, U., \& Homburg, C. (2010). The information content of the SG\&A ratio. Journal of Management Accounting Research, 22(1), 1-22. https://doi.org/10.2308/jmar.2010. 22.1.1

21. Chen, C. X., Lu, H., \& Sougiannis, T. (2012). The agency problem, corporate governance, and the asymmetrical behavior of selling, general, and administrative costs. Contemporary Accounting Research, 29(1), 252-282. https://doi.org/10.1111/j.1911-3846.2011.01094.x

22. Kim, J. B., Lee, J. J., \& Park, J. C. (2019). Internal control weakness and the asymmetrical behavior of selling, general, and administrative costs. Journal of Accounting, Auditing and Finance. https:// doi.org/10.1177/0148558X19868114

23. Ballas, A., Naoum, V. C., \& Vlismas, O. (2020). The effect of strategy on the asymmetric cost behavior of SG\&A expenses. European Accounting Review, forthcoming. https://doi.org/10.1080/ 09638180.2020 .1813601

24. Kama, I., \& Weiss, D. (2013). Do earnings targets and managerial incentives affect sticky costs? Journal of Accounting Research, 51(1), 201-224. https://doi.org/10.1111/j.1475-679X.2012. 00471.x

25. Li, W. L., \& Zheng, K. (2020). Rollover risk and managerial cost adjustment decisions. Accounting \& Finance, 60(3), 2843-2878. https://doi.org/10.1111/acfi.12417

26. Dierynck, B., Landsman, W. R., \& Renders, A. (2012). Do managerial incentives drive cost behavior? Evidence about the role of the zero earnings benchmark for labor cost behavior in private Belgian firms. Accounting Review, 87(4), 1219-1246. https://doi.org/10.2308/accr-50153

27. Dalla Via, N., \& Perego, P. (2013). Sticky cost behavior: Evidence from small and medium sized companies. Accounting \& Finance, 54(2012), 753-778.

28. Hall, C. M. (2016). Does ownership structure affect labor decisions? Accounting Review, 91(6), 1671-1696. https://doi.org/10.2308/accr-51384

29. Prabowo, R., Hooghiemstra, R., \& Van Veen-Dirks, P. (2018). State ownership, socio-political factors, and labor cost stickiness. European Accounting Review, 27(4), 771-796. https://doi.org/ 10.1080/09638180.2017.1329659

30. Costa, M. D., \& Habib, A. (2020). Trade credit and cost stickiness. Accounting \& Finance, forthcoming. https://doi.org/10.1111/acfi.12606

31. Calleja, K., Steliaros, M., \& Thomas, D. C. (2006). A note on cost stickiness: Some international comparisons. Management Accounting Research, 17(2), 127-140. https://doi.org/10.1016/j.mar. 2006.02.001

32. Cannon, J. N. (2014). Determinants of "sticky costs": An analysis of cost behavior using United States air transportation industry data. Accounting Review, 89(5), 1645-1672. https://doi.org/10. 2308/accr-50806

33. Novák, P., \& Popesko, B. (2014). Cost variability and cost behaviour in manufacturing enterprises. Economics and Sociology, 7(4), 89-103.

34. Noreen, E., \& Soderstrom, N. (1997). The accuracy of proportional cost models: evidence from hospital service departments. Review of Accounting Studies. https://doi.org/10.1023/A:10183 25711417

35. Balakrishnan, R., Petersen, M. J., \& Soderstrom, N. S. (2004). Does capacity utilization affect the "stickiness" of cost? Journal of Accounting, Auditing \& Finance, 19(3), 283-299. https://doi. org/10.1177/0148558X0401900303

36. Nagasawa, S. (2018). Asymmetric cost behavior in local public enterprises: Exploring the public interest and striving for efficiency. Journal of Management Control, 29(3), 225-273. https://doi. org/10.1007/s00187-018-0269-x

37. Anderson, M. C., Banker, R. D., Huang, R., \& Janakiraman, S. (2007). Cost behavior and fundamental analysis of SG\&A costs. Journal of Accounting, Auditing \& Fincance, 22(1), 1-28. https://doi.org/10.1177/0148558X0702200103 
38. Yasukata, K., \& Kajiwara, T. (2011). Are "sticky costs" the result of deliberate decision of managers? SSRN Electronic Journal. https://doi.org/10.2139/ssrn.1444746

39. Cooper, R., \& Kaplan, R. (1992). Activity-based systems: Measuring the costs of resource usage. Accounting Horizons, 6(3), 1-13.

40. Opie, R. (1931). Marshall's time analysis. The Economic Journal, 41(162), 199-215. Retrieved from https://www.jstor.org/stable/2223698?seq=1

41. MacDougall, G. D. A. (1936). The definition of prime and supplementary costs. The Economic Journal, 46(183), 443-461. Retrieved from https://www.jstor.org/stable/2224883

42. Schneider, E. (1960). Contabilidad industrial. Aguilar.

43. Johnson, H. T., \& Kaplan, R. S. (1987). Relevance lost. The rise and fall of management accounting. Harvard Business School Press.

44. Cooper, R., \& Kaplan, R. S. (1987). How cost accounting systematically distorts products. In W. J. Bruns \& R. S. Kaplan (Eds.), Accounting \& management: Field study perspectives (pp. 204-228). Harvard Business School Press.

45. Cooper, R., \& Kaplan, R. (1991). Profit priorities from activity-based costing. Harvard Business Review, 69(3), 130-135.

46. Shank, J. K., \& Govindarajan, V. (1988). The perils of cost allocation based on production volumes. Accounting Horizons, 2(4), 71-79.

47. Miller, J. G., \& Vollmann, T. E. (1985). The hidden factory.: EBSCOhost. Harvard Business Review, (September-October), 142-150. Retrieved from http://web.a.ebscohost.com.manchester. idm.oclc.org/ehost/pdfviewer/pdfviewer?vid=1\&sid=3d384ac2-6ba9-4543-9abb-ab4d637589 $7 \mathrm{e} \% 40$ sessionmgr4007

48. Banker, R. D., Potter, G., \& Schroeder, R. G. (1995). An empirical analysis of manufacturing overhead cost drivers. Journal of Accounting and Economics, 19(1), 115-137. https://doi.org/10. 1016/0165-4101(94)00372-C

49. Noreen, E., Noreen, E., \& Soderstrom, N. (1994). Are overhead costs strictly proportional to activity?. Evidence from hospital departments. Journal of Accounting and Economics, 17(1-2), 255278. https://doi.org/10.1016/0165-4101(94)90012-4

50. Drury, C. (2018). Management and cost accounting (10th ed.). Cengage.

51. Noreen, E. (1991). Conditions under which activity-based cost systems provide relevant costs. Journal of Management Accounting Research, 3, 159-168.

52. OECD/G20. (2015). Base erosion and profit shifting project. Addressing the tax challenges of the digital economy. Action 1: 2015 Final report. Addressing the tax challenges of the digital economy. https://doi.org/10.1787/9789264237858-zh

53. International Labour Organization. (2016). Non-standard employment around the world. Understanding challenges, shaping projects. Geneva: International Labour Office - Geneva. Retrieved from http://www.ilo.org/wcmsp5/groups/public/---dgreports/---dcomm/---publ/documents/publi cation/wcms_534326.pdf

54. Frecknall Hughes, J., \& Glaister, K. (2001). Electronic commerce and international taxation: A square peg in a round hole? European Management Journal, 19(6), 651-658. https://doi.org/10. 1016/S0263-2373(01)00090-1

55. Li, J. (2003). International taxation in the age of electronic commerce: A comparative study. Canadian Tax Foundation.

56. Saini, A., \& Johnson, J. L. (2005). Organizational capabilities in e-commerce: An empirical investigation of e-brokerage service providers. Journal of the Academy of Marketing Science, 33(3), 360375. https://doi.org/10.1177/0092070305276150

57. Lee, C.-S. (2001). An analytical framework for evaluating e-commerce business models and strategies. Internet Research: Electronic Networking Applications and Policy, 11(4), 349-359.

58. Zeng, D. (2001). Managing flexibility for inter-organizational electronic commerce. Electronic Commerce Research, 1(1/2), 33-51. https://doi.org/10.1023/A:1011519511640

59. Bieńkowska, J., \& Sikorski, C. (2016). Hyperflexibility A feature of e-commerce organisations. Management, 20(2), 210-223. https://doi.org/10.1515/manment-2015-0061

60. Holzhacker, M., Krishnan, R., \& Mahlendorf, M. D. (2015). The impact of changes in regulation on cost behavior. Contemporary Accounting Research, 32(2), 534-566. https://doi.org/10.1111/19113846.12082

61. Steinfield, C., Bouwman, H., \& Adelaar, T. (2002). The dynamics of click-and-mortar electronic commerce: Opportunities and management strategies. International Journal of Electronic Commerce, 7(1), 93-119. https://doi.org/10.1080/10864415.2002.11044254 
62. Menard, S. (2005). Applied logistic regression (2nd ed.). SAGE Publications.

63. Kutner, M. H., Nachtsheim, C. J., Neter, J., \& Li, W. (2005). Applied linear statistical models (5th ed.). McGraw-Hill Irwin.

64. Belsley, D. A., Kuhn, E., \& Welsch, R. E. (2004). Regression diagnostics. Identifying influential data and sources of collinearity. Wiley-Interscience.

65. Midi, H., Sarkar, S. K., \& Rana, S. (2010). Collinearity diagnostics of binary logistic regression model. Journal of Interdisciplinary Mathematics, 13(3), 253-267. https://doi.org/10.1080/09720 502.2010.10700699

66. Armstrong, C. S., Jagolinzer, A. D., \& Larcker, D. F. (2010). Chief executive officer equity incentives and accounting irregularities. Journal of Accounting Research, 48(2), 225-271. https://doi.org/ 10.1111/j.1475-679X.2009.00361.x

67. Dyreng, S. D., \& Markle, K. S. (2016). The effect of financial constraints on income shifting by US multinationals. Accounting Review, 91(6), 1601-1627. https://doi.org/10.2308/accr-51420

68. Banker, R. D., Byzalov, D., \& Chen, L. T. (2013). Employment protection legislation, adjustment costs and cross-country differences in cost behavior. Journal of Accounting and Economics, 55(1), 111-127. https://doi.org/10.1016/j.jacceco.2012.08.003

69. Golden, J., Mashruwala, R., \& Pevzner, M. (2020). Labor adjustment costs and asymmetric cost behavior: An extension. Management Accounting Research, 46(March), 1-10. https://doi.org/10. 1016/j.mar.2019.07.004

70. Van den Broek, D. (2010). From Terranova to Terra Firma: A critique of the role of free Labour and the digital economy. The Economic and Labour Relations Review, 20(2), 123-134.

71. Friedman, G. (2014). Workers without employers: Shadow corporations and the rise of the gig economy. Review of Keynesian Economics, 2(2), 171-188. https://doi.org/10.4337/roke.2014.02.03

72. Greenwood, B., Burtch, G., \& Carnahan, S. (2017). Unknowns of the gig-economy. Communications of the ACM, 60(7), 27-29. https://doi.org/10.1145/3097349

73. Argilés-Bosch, J. M., Ravenda, D., \& Garcia-blandón, J. (2021). E-commerce and labour tax avoidance. Critical Perspectives on Accounting, 81(102202), 1-22. https://doi.org/10.1016/j.cpa.2020. 102202

74. Tokar, T., Jensen, R., \& Williams, B. D. (2021). A guide to the seen costs and unseen benefits of e-commerce. Business Horizons, 64(3), 323-332. https://doi.org/10.1016/j.bushor.2021.01.002

75. Zhao, Q., Jin, J., Deng, X., \& Wang, D. (2017). Considering environmental implications of distribution channel choices: A comparative study based on game theory. Journal of Cleaner Production, 167, 1155-1164. https://doi.org/10.1016/j.jclepro.2017.08.048

76. Carrillo, J. E., Vakharia, A. J., \& Wang, R. (2014). Environmental implications for online retailing. European Journal of Operational Research, 239(3), 744-755. https://doi.org/10.1016/j.ejor.2014. 05.038

77. Zhang, D., Zhu, P., \& Ye, Y. (2016). The effects of E-commerce on the demand for commercial real estate. Cities, 51, 106-120. https://doi.org/10.1016/j.cities.2015.11.012

Publisher's Note Springer Nature remains neutral with regard to jurisdictional claims in published maps and institutional affiliations. 